\title{
Dialogia käsitteiden valinnasta ja käytöstä \
}

\author{
Kieli-ideologiat tiedekirjallisuuden suomennostyössä
}

\author{
Anne Mäntynen Ja Jyrki Kalliokoski
}

Kääntäjän on otettava työssään jatkuvasti kantaa siihen, miten alkutekstin merkityksiä ilmaistaan käännöksessä. Kääntäminen on toimintaa, jossa kieli-ideologiat ja niiden pohjalta rakentuvat normatiiviset kieltä koskevat käsitykset ohjaavat käännösprosessissa osallisina olevien toimijoiden ratkaisuja ja valintoja hyvin konkreettisesti. Tässä artikkelissa tarkastelemme käännösprosessia ja siihen osallistuvia toimijoita kieli-ideologioiden näkökulmasta. ${ }^{1}$

Tutkimuskohteemme on tiedekirjallisuuden ${ }^{2}$ kääntäminen toimituksellisena prosessina 2000-luvun Suomessa. Tarkasteltavana olevassa prosessissa toimijoita ovat kääntäjä ja kustannustoimittaja. Lähestymistapaamme voi kuvata kirjoittamisen - ja kääntämisen - sosiolingvistiikaksi Lillisin (2013) tarkoittamassa mielessä. Analyysimme kohdistuu siihen, miten kieli-ideologian käsite ja siihen perustuva näkökulma sopivat tieteenalan käsitteistön ja termien käännösprosessin tutkimukseen. Pääkysymyksemme on, mitä käännöksen käsikirjoitusversion leksikaaliset valinnat, kustannustoimittajan niitä koskevat kommentit sekä kääntäjän reaktiot näihin kommentteihin paljastavat kieliideologioista. Artikkelimme etenee seuraavasti: Käsittelemme aluksi lyhyesti kääntämisen normeja ja kieli-ideologian käsitettä, ja pohdimme alustavasti kieli-ideologioiden merkitystä käännöstyön ja sen eri toimijoiden kannalta (luku 1). Tämän jälkeen esittelemme aineiston ja tutkimusmenetelmän (luku 2). Varsinaisessa analyysiosassa (luku 3) tarkastelemme yhden tiedekirjan suomennosluonnoksen käsikirjoitusmerkinnöistä rakentuvia dialogeja, joissa suomentaja ja kustannustoimittaja keskustelevat leksikaali-

1. Artikkelimme on osa Koneen Säätiön rahoittamaa tutkimushanketta Suomentamisen ideologiat ja normit. Esitämme lämpimät kiitokset aineistomme tutkittaville, jotka ovat mahdollistaneet tutkimuksen tekemisen. Lisäksi kiitämme Virittäjän nimettömiä arvioijia rakentavasta ja kannustavasta palautteesta, hankkeen tutkijoita Lea Laitista, Petri Lauermaa, Taru Nordlundia ja Kaarina Pitkänen-Heikkilää, tutkimusavustajia Armi Sinerkaria ja Idastiina Räsästä sekä Outi Paloposkea ja Hélène Buzelinia kaikesta avusta ja kommenteista tutkimuksen eri vaiheissa.

2. Tiedekirjallisuuden sijaan voisi puhua laajemmin tietokirjallisuudesta, mutta tässä artikkelissa fokuksessa oleva aineisto edustaa tietokirjallisuuden yhtä alalajia, akateemista tai tieteellistä kirjallisuutta, ja asettuu tiede- ja tutkimuskirjallisuuden välimaastoon (vrt. Suomen tietokirjailijat ry). Käytämme käsitteitä akateeminen tietokirjallisuus ja tiedekirjallisuus rinnakkain; eron tieto- ja tiedekirjallisuuden välille tekee myös tutkimusta varten haastateltu kääntäjä (ks. esim. 14 s. 510-511). 
sista valinnoista, sekä niistä hahmottuvia kieli-ideologioita. Tutkimuksen kohteena on kolmenlaisia ilmiöitä: ensinnäkin käännösprosessiin osallistuvien suhtautuminen "vieraisiin" aineksiin, toiseksi käännettävän teoksen tieteenalan diskurssille ominaisista ilmauksista käytävät neuvottelut sekä kolmanneksi käsikirjoitusmerkinnöistä rakentuvat keskustelut, jotka koskevat värittyneitä tai historiallisesti latautuneita ilmauksia. Lopuksi (luku 4) käsittelemme lyhyesti kieli-ideologian käsitteen antia kääntämisen tutkimukselle sekä pohdimme käsitteiden kääntämisen kysymyksiä tutkimustulostemme valossa.

\section{Kieli-ideologiat ja kääntämisen normit käännösprosessin näkökulmasta}

Kieli-ideologioilla tarkoitetaan tietyissä konteksteissa käytettävien tai käytettyjen yksittäisten kielellisten resurssien merkitystä, funktiota ja arvoa koskevia käsityksiä (esim. Silverstein 1985; Kroskrity 2004). Kieli-ideologiat ovat yhteisöllisiä, eikä kieli-ideologia käsitteenä viittaa yksilön käsityksiin tai asenteisiin. Kieli-ideologioissa on siis kyse yhteisössä vallitsevista, yhteisistä ja tunnistettavista käsityksistä siitä, mikä on jonkin kielellisen ilmauksen merkitys tai arvo tietyssä kontekstissa ja millaisia sosiaalisia ja kulttuurisia merkityksiä ilmaukset kantavat mukanaan. Diskursiivisen sosiolingvistiikan ja lingvistisen antropologian tutkimusperinteet (esim. Blommaert 2005; Agha 2007; Silverstein 1985) korostavatkin kielen kokonaisvaltaista indeksisyyttä. Kielelliset valinnat kantavat aina mukanaan kontekstia ja aktivoivat sosiaalisia ja kulttuurisia merkityksiä. Kielellisten valintojen ja käytänteiden sekä kieli-ideologioiden välinen suhde ei kuitenkaan ole suoraviivainen: kieli-ideologioita voi pitää metakäytänteinä, jotka eivät välttämättä tule eksplikoiduiksi niissä kielellisissä tilanteissa, joihin ne vaikuttavat (Visakko 2015a: 5). Yksi tapa tutkia kielellisten valintojen ja kieli-ideologioiden välistä suhdetta on tarkastella metadiskurssia, jossa kielellisistä valinnoista keskustellaan, kuten teemme tässä artikkelissa (ks. Woolard 1998: 9; Mäntynen, Halonen, Pietikäinen \& Solin 2012: 333; Piippo 2012: 220-225).

Kieli-ideologiat eivät ole yhtenäisiä, vaan yhteisössä voi samanaikaisesti olla vallalla useita erilaisia, keskenään ristiriitaisiakin ideologioita ja näkemyksissä voi olla vaihtelua esimerkiksi siinä, mikä kielellinen valinta - vaikkapa oma- vai vierasperäiseksi ymmärretty - on oikein tai sopiva ja missä yhteydessä (ks. Mäntynen ym. 2012: 328-329, 331; myös Visakko 2015b: esim. 39-42, 79-82). Valinnat voidaan myös perustella eri tavoin: Omaa kieltä voidaan pitää arvokkaampana kuin vieraita kieliä tai vieraskielisiä ilmauksia ainakin tietyissä yhteyksissä. Toisaalta samaan aikaan voidaan korostaa vierailla kielillä viestimisen tärkeyttä ja liittää vieraskielisyyteen myönteisiä arvoja, kuten esimerkiksi englannin kieleen tieteellisen julkaisemisen kontekstissa, tai kielet voidaan nähdä monikielisyyden ideologian mukaisesti samanarvoisina (esim. rinnakkaiskielisyys yliopistojen kielipoliittisena ohjelmana ks. Suomen kielen tulevaisuus 2009; Helsingin yliopiston kieliperiaatteet 2014; vrt. myös Halonen, Ihalainen \& Saarinen toim. 2014).

Tekstin yksikielisyys, toisin sanoen se, että suomennoksessa pyritään välttämään niin sanottuja sitaattilainoja tai pitempiä ilmauksia vieraalla (esimerkiksi alkuteoksen) kielellä, näyttäisi olevan ainakin oman aineistomme perusteella yksi suomennettua 
tiedekirjallisuutta koskeva normi. Kielenkäyttötilanteissa kieli-ideologiat tulevatkin esiin muun muassa tällaisina normeina. Nämä normit puolestaan vaikuttavat yksittäisiin kielellisiin valintoihin, esimerkiksi valintaan erikielisten ilmausten välillä. Valitut ilmaukset vuorostaan indeksoivat tietynlaisia sosiaalisia ja kulttuurisia merkityksiä, vaikkapa yksikielisyyttä. Yksikielisyyden normi näkyy vahvana myös (länsimaisessa) kielentutkimuksessa, jossa kielen ja sen ilmiöiden kuvaukset eivät juuri ota huomioon yksilön monikielisyyttä ja arjessa kohtaamiemme kielellisten resurssien moninaisuutta (ks. esim. Auer \& Li Wei 2007; Blommaert \& Rampton 2011).

Tiedekirjallisuuden kääntämisessä erilaiset kieli-ideologiat ovat väistämättä läsnä ja keskustelunalaisina, koska prosessiin osallistuu toimijoita, jotka ovat osin samojen, osin eri diskurssiyhteisöjen jäseniä (ks. Swales 1990): yhtäältä on kyse tieteellisen tiedon välittämisestä suomenkieliselle lukijalle, toisaalta tieteellisen yhteisön sisäisestä asiantuntijakielestä ja yhteisön käsitteistä, joiden avulla tullaan osallisiksi myös alan kansainvälisestä tieteellisestä keskustelusta (ks. Mäntynen 2013; 2012: 387-388).

Lähestymme kieli-ideologioita nimenomaan diskurssintutkimuksen näkökulmasta. Kieli-ideologiat rakentuvat diskursseissa; ne ovat dynaamisia ja saavat merkityksensä vuorovaikutuksessa. Kieli-ideologiat ilmenevät toisaalta globaalisti, kielenkäytön makrotasolla, esimerkiksi kielellisiä ja tyylillisiä valintoja koskevina periaatteina ja diskurssiyhteisön käytänteinä, toisaalta paikallisesti, yksittäisissä kielellisissä valinnoissa ja niitä koskevissa arvioinneissa. Kieli-ideologiat kytkeytyvät vallan epäsymmetriaan. Tästä on kyse esimerkiksi silloin, kun tarkastellaan asiantuntemusta tai auktoriteettiasemaa. (Mäntynen \& Solin 2010; Mäntynen ym. 2012.)

Kääntämisen tutkimuksen kannalta kieli-ideologiat liittyvät myös käännösnormien (Toury 1995; Chesterman 2007) käsitteisiin. Toury (1995) puhuu ennakkonormeista ${ }^{3}$ (preliminary norms), jotka säätelevät esimerkiksi sitä, mitä kannattaa kääntää ja mitkä tekstit on tärkeää kääntää. Toinen käännösnormien ryhmä Touryn mukaan ovat alkunormit (initial norms). Tällä käsitteellä hän tarkoittaa muun muassa lähde- ja kohdekielten standardeja ja normeja, jotka liittyvät esimerkiksi oikeakielisyyteen ja kielelliseen purismiin. Kolmas käännösnormien ryhmä ovat toimintanormit (operational norms) eli käännösprosessin aikana tehtyjä päätöksiä koskevat ja niihin vaikuttavat normit esimerkiksi sen suhteen, valitako yleiskielinen ilmaus vai erikoiskielen termi. (Ma.) Voi siis ajatella, että toimintanormit aktivoituvat paikallisella tasolla, kääntäjän yksittäisissä ratkaisuissa ja niitä koskevissa kommenteissa, kun taas ennakko- ja alkunormit vaikuttavat käännöstoimintaan laajemmin, myös makrotasolla. Toisaalta on muistettava, että yksittäisissä käännösratkaisuissa ja niitä koskevissa kommenteissa makrotasonkin normisto aktivoituu: Yksittäisiä käännösratkaisuja koskevia kommentteja ohjaavat kääntäjän ja esimerkiksi käännöstä kommentoivan kustannustoimittajan käsitykset hyvästä kielestä ja standardinmukaisuudesta. Tällöin puheeksi voi nousta myös yksittäisen ilmauksen kääntäminen tai kääntämättä jättäminen. (Ks. Mäntynen 2012: 383-384.)

Tässä artikkelissa tarkastelemme käsitteiden kääntämistä osana käännösprosessia ja käännöksen julkaisuksi toimittamista dialogisesta näkökulmasta, yhteistyönä ja yhteisön hankkeena, emme siis vain kääntäjän näkökulmasta. Tutkimuksemme keskiössä

3. Touryn termien suomennokset Chesterman 2007. 
on kääntäjän ja kustannustoimittajan välinen vuorovaikutus. Käytännössä tutkimuksen kohteena oleva vuorovaikutus on havaittavissa merkintöjen ketjussa, joka muodostuu kustannustoimittajan ja suomentajan vuorollaan suomennosluonnokseen tekemistä kommenteista. Yhteisöllisyys, käsitteiden merkitystä ja käyttöä koskeva yhteisöllinen ymmärrys ja yhteisöjen jäsenyys ovat olennaisia myös normien näkökulmasta. Analysoimaamme tiedekirjojen suomennostyötä eivät säätele vain kääntäjän normit vaan kaikkien niiden yhteisöjen (keskenään kilpailevat) normit, joissa käännöstyöhön osallistuvat ja toisaalta myös käännettävän tekstin potentiaaliset lukijat ovat jäseninä. Yksittäisellä toimijalla voi olla jäsenyyksiä moneen suuntaan. Tiedekirjallisuuden kustannustoimittaja ja kääntäjä ovat paitsi oman professionsa myös yhteisen tieteestä kirjoittamisen ja julkaisemisen alan asiantuntijoita. Kääntäjä voi lisäksi olla suomennettavan tieteenalan edustaja. (Ks. Mäntynen 2013.) Etnografinen aineistomme tuo selvästi esiin sen, että myös tieteelliset kustantamot ovat osa kunkin tieteenalan tiedeyhteisön muodostamaa diskurssiyhteisöä. Käsitys suomen asemasta ja tehtävästä tieteen raportoinnin ja tieteenalan tiedon popularisoinnin kielenä suhteessa muihin kieliin (useimmiten englantiin) on keskeinen osa tätä asiantuntemusta. Tähän kytkeytyy näkemys siitä, millaista kieltä tieteenalalla, sen tulosten julkaisemisessa ja niistä selostamisessa tulisi käyttää. Nämä näkemykset voivat kuitenkin käytännössä vaihdella esimerkiksi sen mukaan, millaisiin muihin diskurssi- tai asiantuntijayhteisöihin käännöksen parissa työskentelevät toimijat kuuluvat tai millaista kielellistä asiantuntijuutta he edustavat.

Diskurssiyhteisön jäsenillä saattaa olla erilaisia käsityksiä siitä, millä ja millaisella kielellä sekä millaisin käsittein ja termein tieteenalan asioista tulee käydä keskustelua. Esimerkiksi koulutetun kääntäjän kielellinen asiantuntijuus on erilaista kuin kustannustoimittajan. Kääntäjällä - tai kustannustoimittajalla - voi puolestaan olla käännettävänä olevan teoksen alan tutkijankoulutus. Se, tunnistaako yksittäisen ilmauksen tieteen- tai erikoisalan termiksi vai ei, vaikuttaa tietenkin myös siihen, minkä tieteen- tai erikoisalan suunnasta käännösvastinetta ryhtyy etsimään. ${ }^{4}$ Tämä tulee esiin myös aineistomme kääntäjän haastattelussa (ks. esim. 14 s. 510-511). Termimäisyydestä ja sen asteesta voi eri toimijoilla olla erilaisia käsityksiä, jotka kytkeytyvät sekä tieteenalaan että esimerkiksi tiettyyn tutkimustraditioon. Tämän artikkelin aineiston haastattelussa kääntäjä kuvaa omaa taustaansa "yleisakateemiseksi" ja kertoo toimineensa akateemisesti muullakin kuin kääntämisen alalla. Käsikirjoitusta ei tutkimassamme tapauksessa ole erikseen lukenut tieteenalan asiantuntija, kuten joskus on tapana (ks. esim. Mäntynen 2012). Artikkelimme aiheen kannalta kiintoisa on myös haastattelussa esiin tullut tieto, että kääntäjä ei itse ottanut yhteyttä kehenkään asiantuntijaan vaan luotti tässä tapauksessa kustannustoimittajaan. Kustannustoimittajalla onkin kääntäjän tulkinnan mukaan ollut myös sisällöllisen asiantuntijan, "asiantuntijalukijan" rooli, kuten hän haastattelussa totesi.

Eri asiantuntijuudet kerrostuvat nimenomaan tieteellisten teosten kääntämisessä, mikä näkyy tämänkin artikkelin aineistossa. Käännösprosessiin osallistuvat asiantuntijat voivat siis samaan aikaan kuulua useaan diskurssiyhteisöön, ja heillä voi siten olla erilaisia, moniulotteisia käsityksiä kielestä ja kielellisten valintojen merkityksestä. Juuri tässä saa kieli-ideologioiden näkökulma merkityksensä.

4. Kiitämme Kaarina Pitkänen-Heikkilää, joka kiinnitti huomiomme tähän seikkaan. 


\section{Aineisto ja tutkimusmenetelmä}

Tutkimuksemme perustuu aineistoon, joka koostuu yhden tiedekirjasuomennoksen eri käsikirjoitusversioista, kustannustoimittajan ja kääntäjän käsikirjoitukseen tekemistä kommenteista sekä kääntäjän haastattelusta ja muista etnografisista havainnoista (ks. tarkemmin Mäntynen 2012). Tutkimuksen kohteena on yhden taloushistorian moderneihin klassikkoihin kuuluvan teoksen suomennoksen editointiprosessi ja erityisesti suomennoksen käsikirjoitus merkintöineen. Aineiston on koonnut Anne Mäntynen, ja se on kerätty yhteistyössä kustantajan ja suomentajan kanssa vuosina 20072009.

Tarkasteltava tutkimusaineisto on koottu etnografisesti. Etnografia on kielitieteessä ja sosiolingvistiikassa perinteisesti yhdistetty nimenomaan suullisten vuorovaikutustilanteitten tutkimukseen (ks. esim. Gumperz \& Hymes toim. 1972) ja samassa tilassa työskentelevien tai opiskelevien toiminnan ja kohtaamisten tutkimukseen (ks. esim. Lappalainen, Hynninen, Kankkunen, Lahelma \& Tolonen toim. 2007). Tässä ymmärrämme etnografian pikemminkin monipuoliseksi metodologiaksi kuin metodiksi ja niin, että tutkimuksen kohteena voi olla myös kirjoitettu vuorovaikutus ja kirjallisten dokumenttien tuottaminen toimintana (ks. Copland, Creese, Rock \& Shaw 2015; Lillis 2008: 362). Akateemisten tekstien ja kirjoittamisen tutkimuksessa etnografian metodologiana on nostanut esiin kirjoittamisen sosiolingvistiikkaa edustava Lillis (mp.; ks. myös Lillis 2013). Hän pitää etnografiselle metodologialle ominaisina erityisesti kahta tutkimusmenetelmää: pitkäaikaista osallistumista kirjoittajien kirjoittamisen maailmaan ("in participants' academic writing worlds") ja erityyppisten aineistojen keräämistä ja analysointia. Lillisin (2008) mukaan nämä kaksi tutkimusmenetelmää ovat keskeisiä silloin, kun tutkimuksen tavoitteena on kirjoittamisen ja tekstien kontekstualisointi. Tällaisen tutkimuksen tavoitteena on hänen (mas. 361-362) mukaansa kuroa umpeen tekstien ja kontekstin välistä kuilua ja siirtää siten tutkimuksen fokusta tuotoksesta esimerkiksi merkitysten rakentumisen prosesseihin (ks. Lillis 2013: 13-15). Samantyyppinen ajatus on ollut esillä myös kääntämisen etnografisessa tutkimuksessa (ks. Buzelin 2007).

Kuten edellä mainitsimme, analyysin kohteena tässä artikkelissa on yhden tiedekirjan suomennoskäsikirjoitus, jossa on kustannustoimittajan ja kääntäjän merkintöjä. Käsikirjoitusten merkinnät ovat multimodaalisia: analyysissa olemme kiinnittäneet huomiota myös kommenttien ulkoasuun ja muihin visuaalisiin piirteisiin (nuolet, rengastukset, merkintöjen väri jne.). Analyysimme kannalta erityisen merkittävää on, että kommentit paikantuvat tiettyyn tekstinkohtaan ja osaksi dialogia nimenomaan nuolin, viivoin ja rengastuksin, kuten kuvassa 1 (seur. sivulla). Lisäksi se, että käsikirjoituksissa kääntäjän ja kustannustoimittajan merkinnät ovat erivärisiä - kääntäjän punaisia ja kustannustoimittajan mustia - on tehnyt dialogin osapuolten erottamisesta mahdollista ja luotettavaa. 


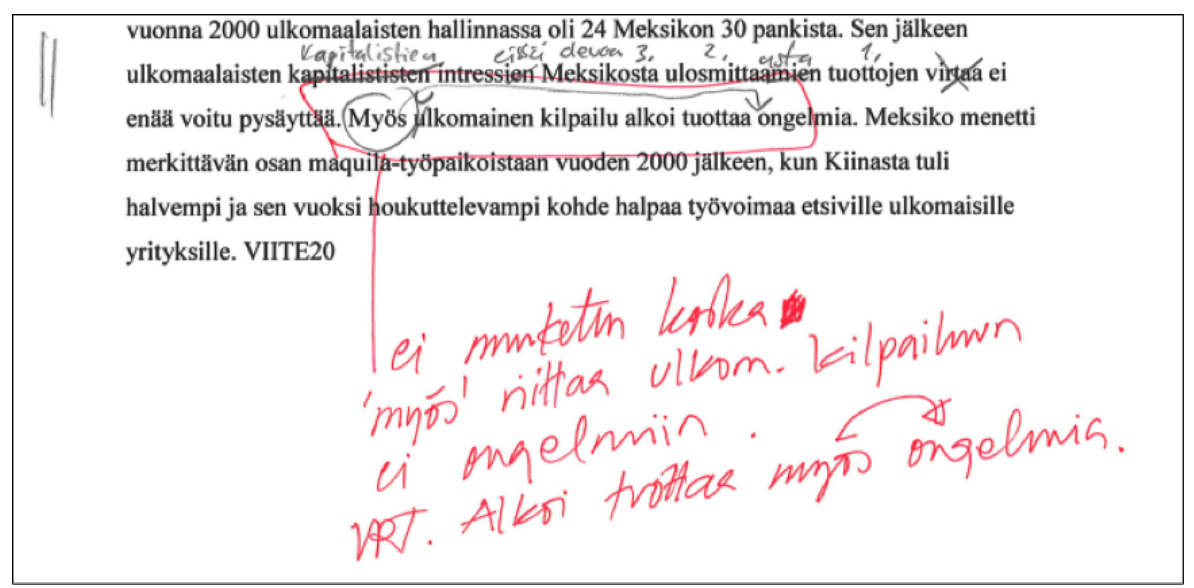

Kuva 1.

Kääntäjän kommentti kustannustoimittajan korjausehdotukseen. (Suomennos, luku 4 s. 16)

Lisäksi tämän artikkelin aineistoon kuuluu Anne Mäntysen tekemä kääntäjän haastattelu, joka on luonteeltaan keskustelunomainen - tässä tapauksessa tutkija ja kääntäjä tunsivat jossain määrin toisensa jo ennen haastattelua. Haastattelu toteutettiin teemahaastatteluna niin, että keskustelun runko perustui muutamaan etukäteen valittuun teemaan mutta eteni melko vapaamuotoisesti keskustellen asiasta toiseen (ks. Tiittula \& Ruusuvuori 2005: 11). Käsikirjoitus- ja keskusteluaineiston lisäksi Mäntynen on ennen hanketta ja sen yhteydessä viettänyt aikaa ja keskustellut hankkeen teemoista muidenkin kääntäjien ja tieteellisten suomennosten parissa työskentelevien kustantamotyöntekijöiden ${ }^{5}$ kanssa ja siten pyrkinyt osallistumaan ja perehtymään suomentamisen maailmaan eri tavoin. Hankkeen aikana on kerätty käsikirjoitus- ja haastatteluaineistoa muidenkin teosten suomennosprosesseista (ks. Mäntynen 2012), ja aineistoon kuuluu myös joihinkin suomennosprosesseihin liittyviä sähköpostiviestejä sekä muistiinpanoja keskusteluista ja havainnoista. Monipuolisen aineiston keräämisen ja edellä kuvatun osallistumisen avulla olemme pyrkineet ymmärtämään sitä kulttuurista ja tilanteista kontekstia, jossa tiedekirjan suomennos syntyy ja jossa siitä neuvotellaan, sekä analysoimaan käsikirjoituksia osana tuota kontekstia.

\section{Miten kieli-ideologiat näkyvät suomennoksissa ja niiden kommen- toinnissa: kolme näkökulmaa}

Analysoimme edellä esitellyn teoksen suomennoksen editointivaihetta kolmesta eri näkökulmasta. Näkökulmien valinta perustuu vahvasti prosessin toimijoiden eli kustannustoimittajan ja kääntäjän kirjalliseen dialogiin sekä tutkijan etnografisiin havaintoihin muun muassa siitä, mitä kääntäjät ja kustantamon edustajat ovat ottaneet

5. Tähän kustantamotyöntekijöiden joukkoon kuului myös tässä artikkelissa esiintyvä kustannustoimittaja. 
esiin keskusteluissa ja haastatteluissa Mäntysen kanssa ja millaisia erityispiirteitä juuri tiedekirjallisuuden suomentamiseen on eri tilanteissa liitetty. Tarkastelemamme näkökulmat kääntäjän ja kustannustoimittajan dialogiin ovat seuraavat: 1) "vieraat" ainekset ja yksikielisyyden ihanne (alaluku 3.1), 2) tieteenalan diskurssille ominaiset ilmaukset (mukaan lukien yleiskieliset ja eri tieteenalojen kielelle ominaiset ilmaukset, alaluku 3.2) ja 3) historiallisesti latautuneet, värittyneet ilmaukset (alaluku 3.3).

Kaikille kolmelle tarkastelukulmalle on yhteistä se, että niiden avulla voimme analyysissamme tuoda esiin toimijoiden välisiä eroja suhtautumisessa siihen, millainen leksikaalinen ilmaus suomennokseen pitäisi valita, mikä olisi oikein tai sopivaa ja millä perusteella. Tarkastelemme analyysissamme vuorovaikutusta paperilla eli käsikirjoituksesta ilmeneviä kustannustoimittajan tekemiä korjausehdotuksia, jotka koskevat kääntäjän käyttämiä tai ehdottamia käsitteitä, sekä niistä käytyä keskustelua: korjausehdotuksia on toisinaan perusteltu, ja toisinaan kääntäjä taas on kommentoinut ehdotusta, siis vastannut siihen (ks. kuvaa 1). Näin on käynyt etenkin silloin, kun kääntäjä on ollut kustannustoimittajan ehdotusta vastaan. Tutkimuksen kohteena oleva suomennoksen editointiprosessi on ollut sillä tavalla poikkeuksellinen, että kääntäjä ja kustannustoimittaja eivät ole käyneet tekstiä lävitse kasvokkain (Tässä ei oo istuttu, ks. esim. $\left.1^{6}\right)$, kuten on kääntäjän mukaan yleensä tapana tehdä. Sen sijaan he ovat keskustelleet käännöksestä nimenomaan käsikirjoitukseen merkityin kommentein, jolloin käsikirjoitukseen on kirjautunut ehkäpä tavanomaista enemmän myös kielellisten valintojen pohdintaa ja perusteluja. Kääntäjä kuvaa haastattelussa omaa osuuttaan dialogista näin:

(1) K: Tässä ei oo istuttu. Sen takia osittain sulla on ne omituiset vastaukset siellä paperissa, että mä tavallaan työstäessäni sitä juttua kävin sitä samaa dialogia, mitä KT:n [kustannustoimittajan] kanssa - - niin paperilla oikeastaan itsellenikin vähän selkiinnyttääkseni sitä, että mitäs mä nyt oon tässä tekemässä, että mitä tässä kommentointiprosessissa mä otan huomioon ja mitä en. Koska sitä [kommentointia] oli niin paljon enemmän ja sitä piti miettiä ja ne [kommentit] oli eritasoisia.

Käännöksen syntaktisiin tai retorisiin rakenteisiin verrattuna alkuteoksessa käytetyt termit ja käsitteet sekä niiden suomennokset ovat konkreettisia ja selvärajaisia tekstinosia, joiden valintaan on helppo tarttua ja joita on helppo kritisoida; niiden puolesta ja niitä vastaan on mahdollista argumentoida tieteenalan sisäisiin käytäntöihin vetoamalla. Käytämme kieli-ideologian käsitettä apuna pyrkiessämme ymmärtämään, miksi kääntäjä tai kustannustoimittaja suosii tiettyä ilmausta ja miksi hän päätyy ehdottamaan toisen käyttämän tai ehdottaman ilmauksen hylkäämistä. On helppo havaita, että kolme näkökulmaamme nostavat esiin kielellisten valintojen subjektiivisen - tai niin kuin tahdomme esittää - ideologisen puolen: kyse ei ole selvärajaisista kategorioista.

6. Haastatteluesimerkkien litteraatteja on tässä luettavuuden parantamiseksi jonkin verran yleiskielistetty; haastatteluaineisto on kuitenkin alun perin litteroitu sanatarkasti (ks. Aineistonhallinnan käsikirja: Kvalitatiivisen datan käsittely, Litterointi). 
Käännösprosessiin osallistuvien toimijoiden on viime kädessä keskenään neuvoteltava, mikä on lukijalle "vieras" ilmaus, mikä ilmaus on erikoiskielen termi ja miten se mahdollisesti eroaa yleiskielen (samanasuisesta) ilmauksesta tai mitä milloinkin tarkoitetaan ilmauksen värittyneisyydellä tai historiallisella latautuneisuudella (Blommaert 2005: 129). Samalla neuvottelu nostaa esiin laajempia tunnistettavia käsityksiä kielestä. Juuri näiden käsitysten eksplikoiminen ja tulkinta on diskurssintutkimuksen keskeinen tehtävä. Analyysimme aikana tulee esiin myös se, että latautuneisuutta on mahdollista jäljittää historiallisesti, tekstiketjuja (Bakhtin 1986: 91-100; Agha 2007: 64-72) seuraten ja tulkiten (vrt. myös Hyvärinen, Kurunmäki, Palonen, Pulkkinen \& Stenius 2003).

\subsection{Purismi ja yksikielisyyden ideologia}

Tarkastelemme tässä alaluvussa sellaisia korjauksia ja korjausehdotuksia, joissa on kyse valinnasta vierasperäisen ja suomenkielisen käsitteen tai ilmauksen välillä. Omaperäisten ja vierasperäisten ilmausten suhde on tavallaan kääntämisen ydintä: vaikka käännöksen yksikkönä on pikemminkin teksti kuin yksittäiset ilmaukset, syntyy kokonainen teksti pintatasolla myös yksittäisten ilmausten kääntämisestä. Hyvän suomennoksen kriteerinä voi pitää paitsi tekstin sujuvuutta myös käsitteiden ilmaisemisen täsmällisyyttä, joka vaikuttaa käännöksen laatuun erityisesti erikoisaloilla (ks. Pasanen 2015). Täsmällisyyden vaatimus tulee esiin myös tutkimushankkeemme kääntäjähaastatteluissa - samoin se, että kääntäjien mukaan oleellista hyvässä käännöksessä on alkuteoksen ajatuksenjuoksun ja argumentoinnin säilyminen sujuvana.

Vieras- ja omaperäisten sanojen suhteella on myös tunnistettava yhteys kieliideologian käsitteeseen. Yhtenä kielenhuollon ideologiana on pidetty purismia, jonka yksi ilmentymä on niin Suomessa kuin muualla ollut "vieraan vaikutuksen", esimerkiksi vierasperäisten sanojen, karttaminen ja omaperäisten ilmaisukeinojen suosiminen (Thomas 1991; Rintala 1998; Nordlund 2004; ks. myös Mäntynen 2012: 402). Käsillä olevan aineiston käsikirjoituksessa onkin havaittavissa systemaattisesti toistuvia korjauksia, jotka kohdistuvat vierasperäisiin sanoihin (ks. alalukua 3.1.1).

Varsinaisen purismin ohella aineistossamme ilmenee myös konkreettinen pyrkimys yksikielisyyteen. Lähdetekstin hankalasti suomennettavia englanninkielisiä ilmauksia ei haluta sisällyttää suomennokseen käännöksen rinnalla, vaikka merkityksen välittymisen näkökulmasta tämä voisi olla hyödyksi. Tätä yksikielisyyden ideologiaa, koodinvaihdon torjuvaa normia, ei kuitenkaan aina seurata: alun perin muista kielistä (aineistossamme esimerkiksi espanjasta) peräisin olevat ilmaukset, jotka jo lähdetekstissä on sekä selitetty että säilytetty alkuperäisessä kieliasussaan, on säilytetty myös suomennoksessa (ks. alalukua 3.1.2). Kahtalaista alkuperää olevan sanaston rinnakkaista käyttöä koskevalla keskustelulla on käännöskirjallisuudessa ja sen tutkimuksessa pitkät perinteet.? Aineistossamme ajoittain esiintyvän suomenkielisen ja alkukielisen ilmauk-

7. Esimerkiksi Leisi (1947) on osoittanut, kuinka keskiajan englantilainen kääntäjä ja kustantaja William Caxton käytti samoissa konstruktioissa rinnan vierasperäistä (ranskalaista) ja kotoperäistä (anglosaksista) ilmausta. Kirjakielen muotoutumisen vaiheessa kotoperäisen ja vierasperäisen ilmauksen rinnakkaiskäytöllä oli Leisin mukaan myös sivistävä tai opettava funktio, kun kotoperäisen avulla selitettiin vierasperäistä ilmausta. 
sen rinnakkaiskäytön voi tulkita vakiintumattomuuden merkiksi: käsite itsessään on vakiintumaton tai sen sovellusala maantieteellisesti rajattu, ja siksi suomennoksen rinnalle on luonnoksessa ehdotettu myös alkuperäistä käsitettä. Tämän ratkaisun toimivuudesta tai sopivuudesta voivat suomentaja ja kustannustoimittaja olla eri mieltä.

Kielellisen purismin ideologia ja vieraiden kielenainesten torjunta ei toki toteudu kautta koko suomennoksen kommentoinnin. Osa vierasperäisiä ilmauksia koskevista keskusteluista lähtee päinvastoin liikkeelle nimenomaan siitä, että suomennosta arvioiva kustannustoimittaja valitsisikin mieluummin vierasperäisen "sivistyssanan" kääntäjän ehdottaman suomenkielisemmän ilmauksen sijaan. Alaluvussa 3.1.3 annamme esimerkkejä myös tällaisista keskusteluista, jotka osaltaan todistavat siitä, että kielenkäyttäjien toiminnan taustalla voi vaikuttaa samanaikaisesti keskenään riidoin olevia kieli-ideologioita.

\subsubsection{Kansainvälisten ilmausten torjuminen}

Käsillä olevassa suomennosprosessin kommentoinnissa näkyy yksi kielellisen purismin ilmentymä, omapohjaisen - tai sellaiseksi kuvitellun - sanaston suosiminen ja vierasperäiseksi koetun sanaston torjuminen käännösratkaisuna (ks. esim. Rintala 1998: 5556). Tällainen omakielisen ilmauksen haku on leimannut perinteisesti kielenhuoltoon ja oikeakielisyyteen liittyvää keskustelua niin Suomessa kuin muualla Euroopassa (Paunonen 1994; Nordlund 2004; Ontermaa 2005; Piippo 2012), ja se on näkynyt esimerkiksi kielenhuoltajien suositusten perusteluissa, joissa vieras vaikutus on yleensä esitetty kartettavana (ks. esim. Saarimaa 1947; Pulkkinen 1974; toisenlaisesta suhtautumisesta vierassanoihin ks. hollannin 1900-luvun lopun kielenhuollon osalta Renkema 1982).

Esimerkit 2-3 kertovat suomennoksen käsikirjoituksessa laajalti esiintyvästä kuviosta: suomentaja on valinnut kansainvälisen sanan, jolla usein on sama kanta kuin alkutekstin englanninkielisellä ilmauksella, ja kustannustoimittaja korvaa sen (enemmän tai vähemmän vakiintuneella) "suomalaisella" sanalla. Kyse on tyylillisestä käytänteestä "suosi suomalaista ilmausta", jonka taustalla voidaan nähdä puristinen kieli-ideologia.

\section{(2) redusoitunut $\rightarrow$ kutistunut}

Vaikka kilpailun erinomaisuutta korostetaan, todellisuudessa uusliberalismi vahvistaa oligopoleja, monopoleja ja muutamien monikansallisten suuryritysten transnationaalista $\left[\rightarrow\right.$ ylikansallista $\left.{ }^{8}\right]$ valtaa: virvoitusjuomien kansainvälinen kilpailu on redusoitunut [ $\rightarrow$ kutistunut] Coca-Colan ja Pepsin väliseksi kilpajuoksuksi; energiateollisuuden osuuksista kisaa viisi jättimäistä moni $[\rightarrow$ yli $]$ kansallista yritystä; muutama mediajätti kontrolloi suurinta osaa tiedonvälityksestä, josta suuri osa on sen vuoksi puhdasta propagandaa. (Suomennos, luku 3 s. 18)

8. Kustannustoimittajan kommentit olemme sijoittaneet hakasulkeisiin ja merkinneet nuolella; kääntäjän ja kustannustoimittajan laajemmat marginaaleihin kirjoitetut kommentit esitämme tarpeen tullen erikseen esimerkkien perässä. Kommenttiesimerkit on merkitty numerolla ja heittomerkillä (4'). Esitämme myös hakasulkeissa lähtötekstin silloin, kun se mielestämme helpottaa esimerkin ymmärtämistä. Esimerkit ovat alkuperäisessä kirjoitusasussa; korostamiseen olemme käyttäneet lihavointia. 
(3) subventoidut $\rightarrow$ julkisin varoin tuetut

Pahinta oli kuitenkin se, että julkinen omaisuus sai vapaasti valua yksityisiin käsiin. Esimerkiksi monet farmaseuttisen [ $\rightarrow$ lääke]tutkimuksen keskeiset läpimurrot oli rahoittanut liittovaltion alainen National Institute of Health yhdessä lääketeollisuuden [ $\rightarrow$ yritysten] kanssa, mutta vuonna 1978 yrityksille $[\rightarrow$ niille] annettiin oikeus kaikkiin patentteihin ilman mitään korvausta valtiolle. Näin taattiin lääkefirmoille [ $\rightarrow$ lääkefirmoille taattiin] mittavat ja laajasti subventoidut $[\rightarrow$ julkisin varoin tuetut $]$ tuotot $[\rightarrow$ voitot $]$ hamaan tulevaisuuteen saakka. (Suomennos, luku 2 s. 15)

[But in 1978 the companies were allowed to take all the benefits of patent rights without returning anything to the state, assuring the industry of high and highly subsidized profits ever after. (S. 52)]

Aina ei ole mahdollista vetää rajaa tyylillisen ihanteen ja tietyn diskurssin (erikoistai ammattikielen, tieteen- tai tiedonalan kielenkäytön) käytänteiden välille. Esimerkin 4 lähdetekstin ilmauksen transnational kääntäjä on suomentanut samakantaisella transnationaalinen-sanalla. Kustannustoimittaja on - samaan tapaan kuin esimerkeissä 2-3 - ehdottanut sen korvattavaksi selittävällä ja kotoperäisellä suomennoksella kansalliset rajat ylittävä. ${ }^{9}$

(4) transnationaalinen $\rightarrow$ kansalliset rajat ylittävä

Luokkasuhteiden radikaali uudelleenjärjestely [ $\rightarrow$ muotoutuminen] nostaa esiin vielä yhden huomionarvoisen pohdinnanaiheen $[\rightarrow$ pohdinnan aiheen]. On kiistelty siitä, onko tämä uusi luokka [ $\rightarrow$ luokkien muotoutuminen] ymmärrettävä transnationaaliseksi [ $\rightarrow$ kansalliset rajat ylittäväksi] vai onko se edelleen tulkittavissa yhden kansallisvaltion rajoissa. Oma näkemykseni on, että valtaapitävä luokka ei ole missään koskaan rajoittanut toimintaansa ja lojaalisuuttaan yhden kansallisvaltion asettamiin rajoihin siinä määrin kuin on haluttu esittää. Ei ole koskaan ollut mielekästä puhua erityisen amerikkalaisesta, brittiläisestä, ranskalaisesta, saksalaisesta tai korealaisesta kapitalistiluokasta. Kansainväliset yhteydet ovat aina olleet tärkeitä, etenkin kolonialistisessa ja uuskolonialistisessa toiminnassa, mutta myös niissä transnationalistisissa [ $\rightarrow$ kansalliset rajat ylittävissä] suhteissa, joiden juuret ulottuvat vähintään 180o-luvulle. Mutta nämä transnationaaliset [ $\rightarrow$ kansalliset rajat ylittävät] yhteydet ovat selvästi sekä syvenneet että laajenneet uusliberalistisen globalisaation aikakaudella, ja on erittäin tärkeää ottaa ne tarkastelussa huomioon. (Suomennos, luku 1 s. 29-30.)

9. Esimerkissä 2 kustannustoimittajan korjausehdotus ilmauksen transnationaalinen sijaan on ylikansallinen. 
[The international links were always important, particularly through colonial and neocolonial activities, but also through transnational connections that go back to the nineteenth century if not before. But there has undoubtedly been a deepening as well as a widening of these transnational connections during the phase of neoliberal globalization, and it is vital that these connectivities be acknowledged. (S. 35)]

Käsikirjoituksen merkinnät kertovat kiinnostavalla tavalla suomentajan ja kustannustoimittajan dialogista. Suomentaja ei ole kustannustoimittajan ehdotukseen tyytyväinen ja esittää neuvoteltavaksi kompromissin:

(4’) Kääntäjän kommentti:

jättäisin miel. ainakin $1 \mathrm{x}$ transnat. indikoimaan mistä engl. käsitteestä suom. kumpuaa. Transnationaalisuus aika paljon puhuttu ihan tuossa lainamuodossakin... ja samalla saa tautologian tässä vähenemään. Toistaiseksi siis jälkimmäinen muuttamatta. Vaihda, jos saat anglismist allergiaa. (Suomennos, luku 1 s. 30)

Suomentajan kommentin kielellisen muotoilun taustalla voi erottaa useampiakin normeja ja kieli-ideologioita. Yksi tietokirjallisuuden ja etenkin tieteellisen teoksen kääntäjän työtä ohjaava periaate on pyrkimys välittää käännöksessä lähdetekstin ilmauksiin sisältyvä informaatio. Tämä näkyy suomentajan kommentissa jättäisin miel. ainakin $1 x$ transnat. indikoimaan mistä engl. käsitteestä suom. kumpuaa. Toisaalta suomentajan kommentin voi tulkita myös niin, että suomentajan näkemyksen mukaan transnationaalinen on teoksen alan (yhteiskuntatieteet, talous- ja sosiaalihistoria) diskurssiin kuuluva käsite (Transnationaalisuus aika paljon puhuttu ihan tuossa lainamuodossakin), ja siksi se tulisi säilyttää myös käännöksessä (ks. tarkemmin alalukua 3.2). Tässä tapauksessa siis nimenomaan kääntäjä tunnistaa ja tulkitsee ilmauksen transnational termiksi. Kääntäjän reaktion verbaalinen muotoilu on myös esimerkki siitä, miten pieneen tilaan (fyysisestikin, paperin reunaan; ks. myös kuvaa 1 s. 498) käännösprosessin neuvottelut ja prosessin toimijoiden dialogin on aineistossamme mahduttava. Lyhyeen kommenttiin sisältyy näkökulmien ja normien runsaus. Kommentissaan suomentaja vetoaa myös tyylinormiin, jonka mukaan saman ilmauksen toistoa, tautologiaa, tulisi välttää. Tässä voi nähdä aktivoituvan selkeyden, kirkkauden tai kenties yksinkertaisuuden estetiikan normin. Vaikka toiston poistaminen juuri tässä ei välttämättä yksinkertaistaisi tekstiä, ideologian tasolla siitä puhuminen nostaa esiin "turhan" poistamisen ja siten pelkistetyn kielenkäytön ihanteen. Tällainen purismi, kielen puhdistaminen turhasta monitulkintaisuudesta, monisanaisuudesta ja hämäryydestä, on rationalismia korostava, valistusfilosofiasta periytyvä kieli-ideologia (Bauman \& Briggs 2003; myös Paunonen 1994: 18; Mäntynen 2003: 145-147), jonka vaikutus tuntuu vahvana kielenhuoltoa ja esimerkiksi virkakieltä koskevassa keskustelussa nykyäänkin (ks. esim. Hyvän virkakielen toimintaohjelma 2014). Toisaalta esimerkin 4' leikillinen sävy korostaa suomennosratkaisua koskevan kääntäjän ja kustannustoimittajan kommentoinnin dialogisuutta: keskustelijat tuntevat toisensa ja voivat laskea leikkiä myös toistensa kieli-ideologisista käsityksistä (Vaihda, jos saat 
anglismist allergiaa); kääntäjä kuvaa haastattelussa kirjoittaneensa kommenttejaan tietoisesti "pehmeesti". Näin kieltä koskeva metapragmaattinen keskustelu (ks. Lucy 1992; Silverstein 1992) nousee itsessään leikkisän kommentoinnin kohteeksi.

Irvine ja Gal (2000) erottavat kieli-ideologioiden taustalla kolmenlaisia semioottisia prosesseja, joita he kuvaavat käsitteillä ikonisuus (iconisation), kertautuvuus (recursivity) ja poistaminen (erasure). Ikonisaation prosessissa jokin esimerkiksi tiettyä sosiaalista merkitystä indeksoiva kielen piirre muuttuu indeksistä ikoniksi, ja kertautuvuus taas kuvaa sellaisia semioottisia prosesseja, joissa jokin asioiden (esim. kielenpiirteen ja sen sosiaalisen merkityksen) välinen suhde siirtyy sellaisenaan suoraan kuvaamaan jotakin toista suhdetta (mas. 37-39; Mäntynen ym. 2012: 330). Poistamisen prosessilla tarkoitetaan esimerkiksi jonkin kielenpuhujaryhmän tai kielimuodon huomiotta jättämistä tai näkymättömäksi tekemistä (Irvine \& Gal 2000: 38-39). Näistä Irvinen ja Galin esittämistä kieli-ideologioita selittävistä semioottisista prosesseista kaksi on näkyvissä suomentajan kommentissa 4': ikonisuus ja kertautuvuus. (Ks. myös Irvine 2001; Mäntynen ym. 2012: 330-331.) Ensinnäkin ikoninen prosessi näkyy suomentajan kommentissa viittauksena siihen, että kustannustoimittajan korjauksen voi tulkita puristiseksi (jos saat anglismist allergiaa) sillä perusteella, että ilmauksen transnationaalinen torjuminen edustaisi (ikonisesti) ylipäätään vierautta torjuvaa puristista kieli-ideologiaa. Toiseksi kertautuvuuden prosessin kannalta suomentajan kommenttia voi tarkastella siitä näkökulmasta, että näin sanoessaan hän väittää kustannustoimittajan kohtelevan ilmausta transnationaalinen yhtenä "allergiaa" aiheuttavana ilmauksena muiden joukossa. Näin ilmauksen vieroksuminen osaltaan ilmentää tietynlaista toistuvaa kieli-ideologista suhtautumista anglismeja kohtaan.

\subsubsection{Yksikielisyyden ihanne: koodinvaihdon torjuminen}

Vierasperäisten sanojen vieroksunnalla on suomen kielen huollossa pitkät perinteet (ks. esim. Kolehmainen 2014). Tähän perinteeseen voi katsoa kuuluvan, ettei suomen kieleen mukauttamattomia sitaattilainoja tai koodinvaihtoa juuri suosita asiaproosassa. Tällaiset ilmaukset uhmaavat yksikielisyyden normia, vakiintunutta käsitystä siitä, että puhuttaessa tai kirjoitettaessa olisi käytettävä kerrallaan yhtä kieltä. Raja mukautetun, "omaksi otetun" lainasanan ja vieraskielisen koodinvaihdon välillä ei ole tietenkään aina kovin selvä - etenkään silloin, kun lainaava ja lainanantajakieli ovat läheisiä sukukieliä tai typologisilta ominaisuuksiltaan esimerkiksi taivutuksen puolesta samankaltaisia. Esimerkki 5 osoittaa kuitenkin, että myös täysin alkukielen mukaisessa kirjoitusasussa olevaa ilmausta voi taivuttaa - jopa silloin, kun sanan fonologinen asu ei ole suomen kielelle tyypillinen (vrt. Hiidenmaa 2003: 95).

\section{(5) think tank $\rightarrow$ ajatushautomo}

Etenkin Yhdysvalloissa joukko rikkaita ja vaikutusvaltaisia yksilöitä ja yritysjohtajia, jotka vastustivat kiivaasti kaikkia valtion intervention ja sääntelyn muotoja ja jopa kansainvälisyyttä, pyrki kokoamaan järjestäytynyttä oppositiota sille konsensukselle, joka heidän mielestään näytti olevan muotou- 
tumassa sekatalousjärjestelmän taakse. Heitä huolestutti, millaiseksi yhteistyö Neuvostoliiton kanssa ja toisen maailmansodan aikana Yhdysvaltoihin muodostunut komentotalous muodostuisivat poliittisesti sodanjälkeisessä maailmassa, ja he olivat valmiit takertumaan kaikkiin keinoihin mccarthylaisuudesta uusliberalistisiin think tank -ajatushautomoihin $[\rightarrow$ think thank =ajatushautomoihin] suojatakseen ja vahvistaakseen omaa valtaansa. Liike pysyi [ $\rightarrow$ jäi] kuitenkin sekä politiikan $[\rightarrow$ ssa] että akateemisen $[\rightarrow$ ssa] vaikutusvallan ulkokehällä [ $\rightarrow$ maailmassa marginaaliin] 1970-luvun vaikeisiin vuosiin saakka. Siinä vaiheessa se alkoi siirtyä kohti keskiötä etenkin Yhdysvalloissa ja Britanniassa. Se sai voimaa erilaisista runsaasti rahoitetuista think tankeista [ $\rightarrow$ ajatushautomoista], jotka olivat Mont Pelerin Societyn satelliittiorganisaatioita [ $\rightarrow$ kaltaisia] - -. (Suomennos, luku 1 s. 17)

Suomentaja käyttää käsikirjoitusversiossa ilmausta think tank, siis englanninkielistä ilmausta suomenkielisessä tekstissä. Ilmaus viittaa tuoreehkoon ilmiöön, jota tarkoittava suomenkielinen ilmaus ei ole välttämättä aivan vakiintunut. Ensimmäisen kerran esiintyessään itse ilmauskin on kaksikielinen ja sisältää selittävän suomenkielisen vastineen (think tank-ajatushautomo), toisella kerralla suomentaja kohtelee sanaliittoa think thank ikään kuin yhdyssanana ja taivuttaa sitä elatiivissa (think tankeista). Kustannustoimittaja puolestaan torjuu tällaisen monikielisyyden suomennoksessa ja on valmis käyttämään johdonmukaisesti pelkkää käännösvastinetta.

Esimerkeissä 6-7 kustannustoimittaja ehdottaa, että käännöksessä käytetyt vieraskieliset ilmaukset (Labour ja Partido Revolucionario Institucional) korvattaisiin suomenkielisillä ilmauksilla.

(6) Labour $\rightarrow$ Työväenpuolue

Labour [ $\rightarrow$ Työväenpuolue] oli 1930-luvulta lähtien rakentanut merkittäviä sillanpääasemia kunnallishallintoon, näyttävimpänä esimerkkinä Herbert Morrisonin johtama Lontoon alueen valtuusto [ $\rightarrow$ kreivikunnanvaltuusto] London County Council [ $\rightarrow$ (London County Council)]. - - 1960-luvun Labour-hallitus [ $\rightarrow$ Työväenpuolueen 1960-luvun hallitus] oli kieltäytynyt lähettämästä joukkoja Vietnamiin, joten maa oli säästynyt epäsuositun sodan aiheuttamilta kotirintaman traumoilta. (Suomennos, luku 2 s. 18)

(7) Partido Revolucionario Institutional ${ }^{10} \rightarrow$ Institutionaalinen vallankumouspuolue

Uusliberalismin kukoistus edellytti, että sosiaalisesti ankkuroidun liberalismin aikainen valtion ja kansakunnan välinen napanuora oli katkaistava. Se oli erityisen tärkeää niissä maissa, kuten Meksikossa ja Ranskassa, jotka saivat $[\rightarrow$ joissa vallitsi] korporatistisen muodon [ $\rightarrow$ korporativismi]. Partitido Revolucionario Institutional -puolueen $[\rightarrow$ Institutionaalisen vallan-

10. Alkuteoksessa Institucional. 
kumouspuolueen] johdolla Meksikon hallinto oli pitkään perustunut ajatukseen valtion ja kansakunnan ykseydestä, mutta 1990-luvun uusliberalistiset ajatukset romuttivat tuon perinteen. (Suomennos, luku 3 s. 22-23)

Huomionarvoista on, että näissä esimerkeissä on kyse erisnimistä; kustannustoimittajan ehdottamat käännökset siis mukauttaisivat suomalaiseen kulttuuriin ulkomaisen puolueen nimen. Näillä erisnimillä on kuitenkin erilainen asema suomenkielisten lukijoiden yhteisössä: Ison-Britannian politiikasta puhuttaessa Työväenpuolue, samoin kuin toki alkuperäinen Labour, on suomalaisessa kielenkäytössä vakiintunut ja tuttu, kun taas Meksikon Partido Revolucionario Institucional ei ainakaan laajalle suomenkieliselle lukijakunnalle ole tuttu sen paremmin espanjan- kuin suomenkielisenäkään. Kustannustoimittajan korjausehdotuksen taustalla on tulkintamme mukaan tässäkin yksikielisyyden normi. Teoksen englanninkielisessä alkutekstissä meksikolaisen puolueen nimi esiintyy alkuperäisessä espanjankielisessä asussaan - ilman, että sitä olisi käännetty englanniksi. Yksikielisyyden ideologian noudattaminen ilmenee siis vain suomennosprosessissa, vaikka tuskin voidaan olettaa, että englanninkielisen alkuteoksen lukijat ymmärtäisivät espanjankielisen ilmauksen paremmin kuin suomenkieliset lukijat.

Esimerkissä 8 kääntäjä on jättänyt vieraskielisen ilmauksen 'looney lefties' käännökseen lainausmerkein (alkutekstissä puolilainausmerkit) ja kustannustoimittaja ehdottaa sen suomentamista ilmauksella kahjot vasurit. Tätä ehdotusta seuraa kääntäjän kommentti, jossa hän vetoaa korrektiiviseen kielinormiin (Rintala 1992; ks. myös Mäntynen 2012: 382) ilmauksella tuntuu pöljältä.

(8) "looney lefties" $\rightarrow$ "kahjot vasurit/vasemmistolaiset"

Aluksi Thatcher vain tylysti leikkasi kuntien valtionosuuksia, mutta monet kunnat vastasivat yksinkertaisesti korottamalla kiinteistö[ $\rightarrow$ omaisuus]veroja, jolloin Thatcherin oli säädettävä laki sitä estämään. Edistykselliset Labour-[ $\rightarrow$ työväenpuolue-enemmistöiset]valtuustot saivat Thatcherilta pilkkanimen "looney lefties" [ $\rightarrow$ "kahjot vasurit/vasemmistolaiset"] (konservatiivinen lehdistö otti siitä kaiken irti) [ $\rightarrow$ (josta koservatiivinen lehdistö otti kaiken irti)], ja hän ryhtyi ajamaan uusliberalistisia uudistuksia kunnallisverouudistuksen kautta [ $\rightarrow$ kuntien rahoitukseen]. (Suomennos, luku 2 s. 22-23)

(8’) Kääntäjän kommentti:

eikö voi jäädä engl? Tuntuu pöljältä, kun loogista suom. ei ole ja joutuu itse keksimään...

Sekä alkuperäisessä että kääntäjän suomentamassa tekstissä looney lefties merkitään vieraaksi lainausmerkeillä, sillä kyse on sitaatista, jonka alkuperäiseksi esittäjäksi nimetään (Margaret) Thatcher. Tämä puolustaisi englanninkielisen ilmauksen ja lainausmerkkien säilyttämistä - autenttisuuden ideologian näkökulmasta. Suomentajan ja kustannustoimittajan ehdotuksia verrattaessa huomio kiinnittyy myös siihen, että suomennok- 
sessa menetetään alkuperäisen ilmauksen allitteraatio. ${ }^{11}$ Toisaalta esimerkin voi tulkita myös Touryn (1995) käännösnormien kannalta. Keskustelu yksittäisen ilmauksen kääntämisestä liittyy toimintanormeihin, kun taas kääntäjän ja kustannustoimittajan dialogi siitä, mitä kieltä tai mitä kieliä suomennoksessa tulee ylipäätään käyttää, koskee pikemminkin Touryn luokittelussa ennakkonormeja (ks. lukua 1).

Kääntäjä mainitsee kommentissaan myös, että "looginen" suomennos puuttuu. Ilmauksen looginen merkitys jää tässä hieman avoimeksi. Se lienee mahdollista tulkita niin, ettei kääntäjällä ole mielessään selvää ehdokasta suomennokseksi. Suomen yleiskielen vakiintumisen näkökulmasta mielenkiintoinen on myös kääntäjän ilmaus joutuu itse keksimään, joka vastaa osuvasti näkemystä siitä, miten kieltä rakennetaan ja keksitään muun muassa sanakirja-, kielioppi- ja käännöstyön yhteydessä (ks. Gal \& Woolard 2001: 1). Esimerkiksi 1800-luvun kääntäjän työssä uusien käännösvastineiden kehittäminen oli keskeinen osa suomennostyötä (ks. Pitkänen-Heikkilä 2018 tässä teemanumerossa). Vaikka suomen yleiskieli on 180o-luvun lopusta lähtien vakiintunut, aineistostamme näkyy, miten muuttuvan yhteiskunnan, uusien ilmiöiden ja niiden luokittelun tarpeisiin syntyy yhä uusia käsitteitä ja termejä. Looginen voi toki viitata myös edellä (s. 503) esillä olleeseen kielen tarkoituksenmukaisuutta ja selvyyttä korostavaan rationalistiseen ideologiaan (ks. Paunonen 1994: 18-19; Rintala 1998: 58-62; Sajavaara 2000: 90-94; myös Bauman \& Briggs 2003).

Esimerkissä 8 ei myöskään oteta puheeksi sellaista ratkaisua, jossa (jo siis alkutekstissä typografisin keinoin lainaukseksi osoitettu) ilmaus 'looney lefties' olisi säilytetty ja sen rinnalla annettu selittävä suomennos (vrt. edellä s. 500). Yksikielisyyden normi ei siis näytä sallivan rinnakkaiskielisyyttä silloinkaan, kun se alkuperäisen ilmauksen merkityksen ja - indeksisen fokuksen (ks. Agha 2007: 26, 169) - ymmärtämiseksi olisi lukijan avuksi. Yksikielisyyden ideologia ohjaa tässä yksittäisen ilmauksen tasolla sekä kustannustoimittajan että kääntäjän valintoja: on käytettävä joko englannin- tai suomenkielistä ilmausta. Kaikkiaan esimerkin 8 keskustelusta näkyy hyvin neuvottelu kääntämisen toimintanormeista, mutta se tuo myös näkyviin sen, miten käännösratkaisuja perustellaan vetoamalla kielen yleisiin korrektiivisiin normeihin tai makrotason ennakkonormeihin. Esimerkkiin sisältyvästä keskustelusta käy myös ilmi yksikielisyyden ideaalin asema suomennostyön kieli-ideologisena kehyksenä.

Yksikielisyyden ihannetta ei kuitenkaan seurata tutkimuksen kohteena olevassa suomennoksen editoinnissa ja kommentoinnissa johdonmukaisesti. Esimerkissä 9 kääntäjä on päätynyt yhdyssanaan piqueteros-ryhmät, jonka perusosa selventää alkuperäistä espanjankielistä käsitettä. Kustannustoimittajan korjausehdotuksessa ovat puolestaan mukana sekä alkutekstissä espanjaksi esiintyvä termi että sille annettu suomenkielinen selitys.

(9) piqueteros-ryhmät $\rightarrow$ piqueterot (katujen mielenosoittajat)

Työttömyys karkasi kasvuun ja tulot romahtivat. Uhmakkaat työläiset valtasivat pysähtyneet tehtaat ja ryhtyivät hommiin, ihmiset kokoontuivat

11. Ilmauksessa kahjot vasurit voi tosin halutessaan nähdä heikkoa allitteraatiota ensitavun vokaalin toiston myötä. 
naapuristokokouksiin etsimään yhteisiä selviytymiskeinoja ja piqueterosryhmät [ $\rightarrow$ piqueterot (katujen mielenosoittajat)] rakensivat tiesulkuja maan valtaväylille poliittisten vaatimustensa tueksi. (Suomennos, luku 4 s. 19)

[Unemployment soared and incomes fell. Idle factories were occupied by militant workers and set to work, neighbourhood solidarity committees were set up to seek better collective mans of survival and the piqueteros (street pickets) blocked transportation networks and mobilized around key political demands. (S. 106)]

Kustannustoimittajan korjausehdotuksen selitys lienee, että myös alkuperäisessä englanninkielisessä tekstissä tämä espanjankielinen termi selitetään. Kustannustoimittajan ehdotus on siis tässä kohdin uskollinen alkuteokselle. Ilmaus piqueteros kuuluu Argentiinan 1990-luvun lopun ja 2000-luvun alun talouskriisiä koskevaan diskurssiin eikä ole helposti käännettävissä suomeksi (tai englanniksikaan) ilman, että jokin olennainen merkitys jää ilmaisematta. Suomennoksen lukijakunnan ja tieteellisen diskurssin kannalta voi olla tärkeää jättää espanjankielinen ilmaus näkyviin muun muassa siksi, että käsite piqueteros voi tulla vastaan muualla saman aihepiirin erikielisissä keskusteluissa ja kirjallisuudessa. Kustannustoimittajan ehdottama ratkaisu tukee ilmauksen indeksisten suhteiden ymmärtämistä tieteenalan sisällä käytävässä keskustelussa.

\subsubsection{Suomenkielisen ilmauksen torjuminen - käänteinen kieli-ideologia?}

Edellä käsitellyissä tapauksissa korjausehdotuksia on perusteltu vetoamalla olemassa oleviin suomenkielisiin vastineisiin. On kuitenkin olemassa myös kilpailevia strategioita ja kieli-ideologioita. Aineistomme osoittaa, ettei yksittäisen kielenkäyttäjän eikä edes toisen kielellisiä ratkaisuja kommentoivan kustannustoimittajan suhtautuminen kotoperäisten, suomalaisten ilmausten ja "vieraskielisten" ilmausten keskinäiseen asemaan tai etusijaisuuteen ole johdonmukaista tai yksiulotteista vaan että käännösprosessissa nousee paikallisesti esiin monenlaisia kieli-ideologioita. Tämä näkyy seuraavista esimerkeistä (10-13).

\section{(10) tieto $\rightarrow$ informaatio}

Samalla kun uusliberalismin mukaan markkinoilla tapahtuva vaihto on arvokasta "itseisarvoisena etiikkana, joka kykenee ohjaamaan ihmisten toimintaa ja korvaamaan aiemmat eettiset ajattelutavat", se korostaa sopimuksenvaraisia suhteita markkinoilla, Sen mukaan yhteinen hyvä voidaan maksimoida maksimoimalla markkinoilla tapahtuvien liiketoimien laajuus ja taajuus $[\rightarrow$ vaihtotoimien vaikutusala ja määr] ja se pyrkii tuomaan kaiken inhimillisen toiminnan markkinoiden piiriin. Se [ $\rightarrow$ Tämä] edellyttää tiedon luomisen teknologiaa [ $\rightarrow$ informaatioteknologian kehittämistä] ja kykyä kerätä, varastoida, siirtää, analysoida ja käyttää valtavan suuria tietokantoja, joiden avulla globaalien markkinoiden päätöksentekoa ohjataan. Siitä syystä uusliberalismi 
on ollut intohimoisen kiinnostunut informaatioteknologiasta ja sen edistämisestä (siinä määrin, että on jo puhuttu jonkinlaisen uuden "tieto[ $\rightarrow$ informaatio]yhteiskunnan" syntymisestä). Teknologia on tiivistänyt markkinatoimien tiheyttä niin tilassa kuin ajassakin. (Suomennos, johdanto s. 3)

(10’) Kustannustoimittajan merkintä tekstin marginaalissa: tieto $\neq$ informaatio

(11) yhteisöllisyys $\rightarrow$ sosiaalisuus

Yleisen arkiajattelun taustalla olevat kulttuuriset ja poliittiset perinteet ovat siten osaltaan vaikuttaneet siihen, missä määrin yksilönvapauden ja vapaan markkinatalouden ihanteet ovat eri maissa saaneet valtaa suhteessa muihin yhteisöllisyyden [ $\rightarrow$ sosiaalisuuden] muotoihin. (Suomennos, luku 4 s. 30)

(12) vastaliike $\rightarrow$ oppositio

On olemassa toinenkin syy siihen, miksi tämä vastaliike [ $\rightarrow$ oppositio] on viime vuosina niin merkittävästi voimistunut. (Suomennos, luku 6 s. 27)

(13) rahoitus- $\rightarrow$ finanssi-

Kehittyvät maat eivät kuitenkaan ole ollenkaan vakuuttuneita siitä, että uusliberalistinen tie on se oikea, etenkään kun maat, jotka eivät olleet vapauttaneet pääomamarkkinoitaan (esimerkiksi Taiwan ja Kiina), selvisivät vuosien 1997-98 rahoituskriisistä [ $\rightarrow$ finanssikriisistä] huomattavasti vähemmin vaurioin kuin ne jotka olivat. (Suomennos, luku 3 s. 9-10)

Esimerkeissä 10-13 kustannustoimittajan korjausehdotuksissa suositaan vierasperäistä (kansainvälistä) ilmausta tavalla, joka muistuttaa Irvinen (2001) hienostuneen puheen ideologiaa (the ideology of elevated speech). Kielenhuollon perinteessä luonnollistuneen (Fairclough 1992) vieraan vaikutuksen torjunnan ohella aineistomme kääntäjän ja kustannustoimittajan vuorovaikutuksessa on siis mukana myös kilpailevia voimia, kuten pyrkimys kansainvälisempään ja siten hienostuneempaan ilmaisuun. Esimerkki 10 havainnollistaa myös, miten "vieras" ja kotoperäinen ilmaus voivat olla vaihtelussa, mahdollisesti esimerkiksi toiston välttämiseksi. (Tässä tosin kustannustoimittajan muutosehdotukset noudattavat vaihtelemattomuuden linjaa.) Esimerkin 13 muutosehdotusta yhdyssanan määriteosaksi (rahoitus- $\rightarrow$ finanssi-) voinee tulkita myös niin, että kustannustoimittaja hakee kotoperäisen ilmauksen tilalle tieteenalalla vakiintuneempaa, mielestään kyseisessä kontekstissa laajemmassa käytössä olevaa käsitettä. Tätä tulkintaa tukee se, että hän on järjestelmällisesti korjannut suomennoksessa yhdyssanan määriteosan rahoitus- ilmaukseksi finanssi-. Tällaisia tapauksia käsittelemme seuraavassa alaluvussa. Kaikkiaan tämän alaluvun esimerkeissä esiin tulleet kilpailevat ja ristiriidassa olevat kieli-ideologiat todistavat omalta osaltaan kielen 
- kieltä koskevien ideologisten järjestelmien ja rakennelmien - polysentrisyydestä eli siitä, että käännösprosessissa suuntaudutaan samanaikaisesti useisiin eri normeihin ja normijärjestelmiin (Blommaert 2005: 75-77; 2010: 39-41).

\subsection{Kontekstisidonnaiset, diskurssille ominaiset ilmaukset}

Tässä alaluvussa otamme esiin tapauksia, joissa keskustelun ja neuvottelun kohteeksi tulevat tieteenalan tai aihealueen diskurssille ominaiset ilmaukset. Erityisesti tieteellisen tekstin käsitteiden suomentamisessa kääntäjän on tärkeää olla tietoinen tieteenalan tai tietyn tutkimusperinteen totunnaisista tavoista puhua ja kirjoittaa, jotta käännös tavoittaisi kohdeyleisönsä ja asettuisi osaksi jo olemassa olevaa diskurssiyhteisön käsitteistöä ja puhetapaa. Kaikki hankkeessa mukana olleet kääntäjät mainitsevat tämän haastatteluissa; kiinnostavaa on, että juuri tästä näkökulmasta kääntäjät pitävät tärkeänä asiantuntijalukijoita tai sitä, että kustannustoimittajalla on teoksen alaa koskevaa asiantuntemusta. Tässä tarkasteltavan suomennoksen kääntäjä kuvailee tiedekirjallisuuden kääntämisen konteksteja ${ }^{12}$ ja erityisesti tiedeyhteisön sekä oman akateemisen taustansa merkitystä muun muassa näin:

(14) K: - - ehkä se ero verrattuna sekä tietokirjallisuuteen että kaunokirjallisuuteen tulee siitä, että ei voi kääntäjänä asettaa samalla tavalla itseään lukijaksi, kun ikään kuin yleensä ei ole liikkumassa omalla alallaan. Ja tavallaan tiedekirjallisuus on keskustelua enemmän siinä yhteisössä, ja tietokirjallisuus taas puolestaan on ikään kuin siitä yhteisöstä tai asiantuntijalta mutta kuitenkin vähän laajemmalle yleisölle.

[Keskustelua poistettu.]

K: Joo, että ne lukijat tietää siitä jutusta enemmän kuin sinä. Ja tavallaan ei ole välttämättä kauhean helppo löytää sitä - - että mikä on selitettävä ja mikä on esimerkiksi puhumisen tapa - - se, että mihin sitoudut, kun valitset jonkun tietyn puhetavan ja mistä tiedät, mihin tulit sitoutuneeksi.

- - Että tavallaan kiistanalaiset, että onko tää käsite nyt tää vai toi, - - mä itse ainakin koen jotenkin omalla taustallani, mä ajattelin, että mä pystyn operoimaan tiedekirjallisuuden parissa nimenomaan kääntäjän kompetenssilla sen vuoksi, että mulla on tämä yleisakateeminen tausta. Mutta mä olisin melko heikoilla vesillä usein, jos mä en itsekin lukisi erilaisia tieteellisiä tekstejä eri tieteenaloilta, ja tavallaan se mun osaaminen sillä suunnalla rakentuu sen varaan, että mä oon kuitenkin työskennellyt myös muilla aloilla kuin käännöstieteessä jossain roolissa. Ja tietokirjallisuudessa jotenkin kään-

12. Esimerkistä 14 käy ilmi rajanveto tieto- ja tiedekirjallisuuden suomentamisen välillä sekä kääntäjän näkemys siitä, miten nämä erot vaikuttavat kääntämiseen. Tämän sinänsä kiinnostavan aiheen syvempään käsittelyyn ei tässä valitettavasti ole tilaa. 
täjän perusammattitaitoon kuuluva tiedonhaku ja semmonen osaaminen auttaa pidemmälle. Että sä voit perustella esimerkiksi jotkut termivalinnat sillä, että niitä suosittelee joku tai ne on yleisesti käytössä arkikielessä tai että niitä ihmiset ymmärtää. Mutta se sama peruste ei välttämättä vie sua yhtään mihinkään siinä tiedekirjallisuudessa, jossa se saattaa olla just se syy, miksi just sitä [termiä] sä et halua käyttää.

Haastattelusta käy ilmi, että kääntäjä saattaa tavallaan tasapainotella käsitteen valinnassa myös tieteenalan käsitteistä käydyn keskustelun perusteella (kiistanalaiset, että onko tää käsite nyt tää vai toi). Kääntäjän on jotenkin saatava selville tai oltava tietoinen siitä, mikä on tiedeyhteisön tapa puhua ja miten teos liittyy tiedeyhteisön keskusteluun. Tiedeyhteisö laajasti ymmärrettynä (tutkijat, alan opiskelijat, alan muissa ammateissa toimivat ja alaa seuraavat harrastajat) on diskurssiyhteisönä myös normatiivinen, mikä vaikuttaa osaltaan tiedekirjallisuuden suomentamiseenkin. Normatiivisuus ilmenee yhtältä suhteessa suomen kirjoitetun yleiskielen normeihin ja niiden taustalla oleviin ideologioihin (purismi, selkeys ym.) ja toisaalta tieteellisen kielenkäytön ja kunkin tieteenalan kielen normeihin, jotka tietenkin ovat osin päällekkäisiä yleiskielen normiston kanssa.

Edellä esimerkissä 4 käsitteen transnational suomennosta koskeneessa keskustelussa tuli esiin yhtenä argumenttina käsitteen vakiintuneisuus tieteenalalla (vrt. myös esim. 13). Suomentaja kirjoitti: Transnationaalisuus aika paljon puhuttu ihan tuossa lainamuodossakin... (s. 503). Paljastavaa on tämän argumentin kielellinen rakentuminen: suomentaja viittaa summittaiseen tuntumaan tai subjektiiviseen arvioonsa vierasperäisen termin yleisyydestä (tieteenalalla) kommentoimalla aika paljon puhuttu. Tällaisten arvioiden varassa tiedetekstiä kääntävä joutuneekin toimimaan niin kauan kuin esimerkiksi isoja korpuksia eri tieteenalojen teksteistä ei ole saatavilla. Toki apua käsitteiden kääntämisen pulmiin tarjoaa tiedetekstien kääntäjille jo nyt esimerkiksi Tieteen termipankki ja sen sivuilla käytävät keskustelut, mutta kuten edellä olevasta haastattelusta käy ilmi, myös kääntäjän tiedonhakutaidot ja oma tausta esimerkiksi tutkijana ja tiedeyhteisön jäsenenä vaikuttavat käsitteiden kääntämiseen (ks. myös Vilokkinen 2017).

Esimerkissä 15 on kysymys ilmauksen commodity suomennoksesta. Kääntäjä on tässä valinnut taloustieteellisessä diskurssissa yleisesti käytetyt ilmaukset hyödyke ja tuotantotekijä. Kustannustoimittajan kommentit puolestaan liittyvät siihen, että hänen mukaansa näissä kohdissa suomennettavana olevan alkuteoksen käsittelemä näkökulma on nimenomaan marxilaisen yhteiskunta- ja talousteorian ja tämän tulisi heijastua myös suomenkielisten käsitteiden valintaan.

(15a) hyödyke $\rightarrow$ tavara

Kansainvälistä kilpailua pidetään tervehdyttävänä, koska se parantaa tehokkuutta, alentaa hintoja ja siten hillitsee [ $\rightarrow$ hillitsee siten] inflaatioalttiutta. Valtioiden tulee sen vuoksi yhdessä pyrkiä vähentämään pääomien vapaan liikkuvuuden esteitä ja avata niin tavaroiden kuin pääomien[+kin] markkinoita maailmanlaajuiselle vaihdolle. Kiistanalaista on kuitenkin se, koskeeko tämä myös hyödykkeeksi [ $\rightarrow$ tavaraksi] nähtyä työvoimaa. (Suomennos, luku 3 s. 3) 
[Whether or not this applies to labour as a commodity is, however, controversal. (S. 66)]

(15a') Kustannustoimittajan kommentti: marxilaisille työvoima on tavara;

(15b) hyödyke/tuotantotekijä $\rightarrow$ tavara

Luokkavallan palauttamisen tavoite johtaa etenkin kahdella osa-alueella uusliberalistisen teorian venyttämiseen ja jopa teorialle vastakkaisiin käytännön toimintamalleihin. Ensimmäinen niistä syntyy tarpeesta luoda "yritys- ja sijoittajamyönteiset olosuhteet" kapitalististen hankkeiden tueksi. Vaikka osa edellytyksistä, esimerkiksi poliittisten olojen vakaus, laillisuuden kunnioittaminen ja lakien oikeudenmukainen soveltaminen, joita voidaan pitää luokan suhteen neutraaleina, jotkut edellytykset ovat ilmeisen puolueellisia. Puolueellisuutta synnyttää ennen kaikkea työvoiman ja ympäristön kohteleminen pelkkinä hyödykkeinä/tuotantotekijöinä [ $\rightarrow$ tavaroina]. Konfliktitilanteessa tyypillinen uusliberalistinen valtio asettuu pikemmin puolustamaan yrityksille suotuisaa ilmapiiriä kuin työvoiman kollektiivisia oikeuksia (ja elämänlaatua) tai luonnon uusiutumiskykyä. (Suomennos, luku 3 s. 7-8)

[The biases arise in particular out of treatment of labour and the environment as mere commodities. (S. 70)]

(15b') Kustannustoimittajan kommentti:

Marxin yksi perusideoista on, että työvoima on tavara!

Esimerkki 15 osoittaa, miten tiedekirjan käännöksessä käytettävien käsitteiden suomennosvarianttien valinnan onnistumista punnitaan sekä tieteenalan yleisen diskurssin että kunkin tutkimusperinteen tai koulukunnan vakiintuneen diskurssin ja normiston näkökulmasta. Kirjan yleisön kannalta tämä tarkoittaa, että esimerkiksi klassikkoteosten (joita suomennettavat tiedekirjat usein ovat) lukijakunta voi olla paitsi jonkin nimenomaisen suuntauksen tai koulukunnan edustajia myös laajemmin alan asiantuntijoita ja muita tieteenalasta kiinnostuneita. Esimerkissä 15 suomentajan ja kustannustoimittajan sopivaa suomennosta koskevat erilaiset näkemykset voi tulkita juuri kahdenlaista lukijakuntaa tai lukijapositiota edustaviksi. Tietyssä tutkimusperinteessä syntyneet tekstit ovat dialogissa keskenään, ja keskeisen käsitteistön käyttö vakiintuu ajan myötä tekstistä toiseen. Pennycook (2010: 46-48) puhuu kerrostuneista diskursseista (sedimented discourse) ja Blommaert (2005: 126-131) kerroksellisesta samanaikaisuudesta (layered simultaneity). Kustannustoimittajan (kiihkeästi, huutomerkin kera!) tarjoama suomennosvaihtoehto tavara on yleiskielen ilmaus, jonka arkinen merkitys sopii - ainakin metaforisesti - myös suomennoksen kontekstiin. Kustannustoimittaja kuitenkin sijoittaa ilmauksen tavara marxilaisen talousteorian kontekstiin: alkutekstin commodity tulisi suomentaa ilmauksella tavara, joka hänen 
mukaansa on nimenomaan suomennettavan teoksen edustamassa tutkimusperinteessä eli marxilaisessa taloustieteessä käytetty käsite. Suomentajan ja kustannustoimittajan neuvottelun sopivasta ratkaisusta mahdollistaa myös ilmauksen tavara polyseeminen merkityspotentiaali. Käsitteen kokonaisvaltaiseen tulkintaan tarvitaan paitsi yleisesti taloustieteen ja sen tekstistön myös eri taloustieteen haarojen kielenkäytön perinteiden tuntemusta. Suomentajan ja suomennosprosessiin osallistuvien tulee siis työssään ottaa huomioon näiden erilaisten diskurssiyhteisöjen ja lukijakuntien kielenkäytön ja tulkinnan konventiot ja normit sekä se, että julkaistavan teoksen lukijakunta voi olla heterogeeninen muun muassa siltä osin, millainen pääsy lukijoilla on tieteenalan ja tutkimusperinteen eri tekstikerrostumiin ja niissä käytettyjen käsitteiden merkityshistoriaan.

Täsmällisen termistön tuntemus on keskeinen osa tieteenalan kielen, kuten yleensäkin erikoiskielten, hallintaa. Aineistossamme näkyy kiinnostavalla tavalla myös se, että suomennostyötä tekevien asiantuntemus ei aina riitä ja että kääntämisen ja kustantamisen ammattilaiset ovat tästä tietoisia ja pyrkivät ratkaisemaan ongelmia dialogissa. Esimerkki 16 (ks. myös kuvaa 2) on yksi rivi teoksessa olevan kuvion tekstityksestä. Kuvio esittää kansainvälisen velkakriisin kehittymistä vuosina 1982-1985.

(16) Brasilia 106/38,6 Brasilian ulkomainen velka yhteensä 106 miljardia, velkaantumisaste? $38,6 \%$ (Suomennos, luku 4 s. 8 )

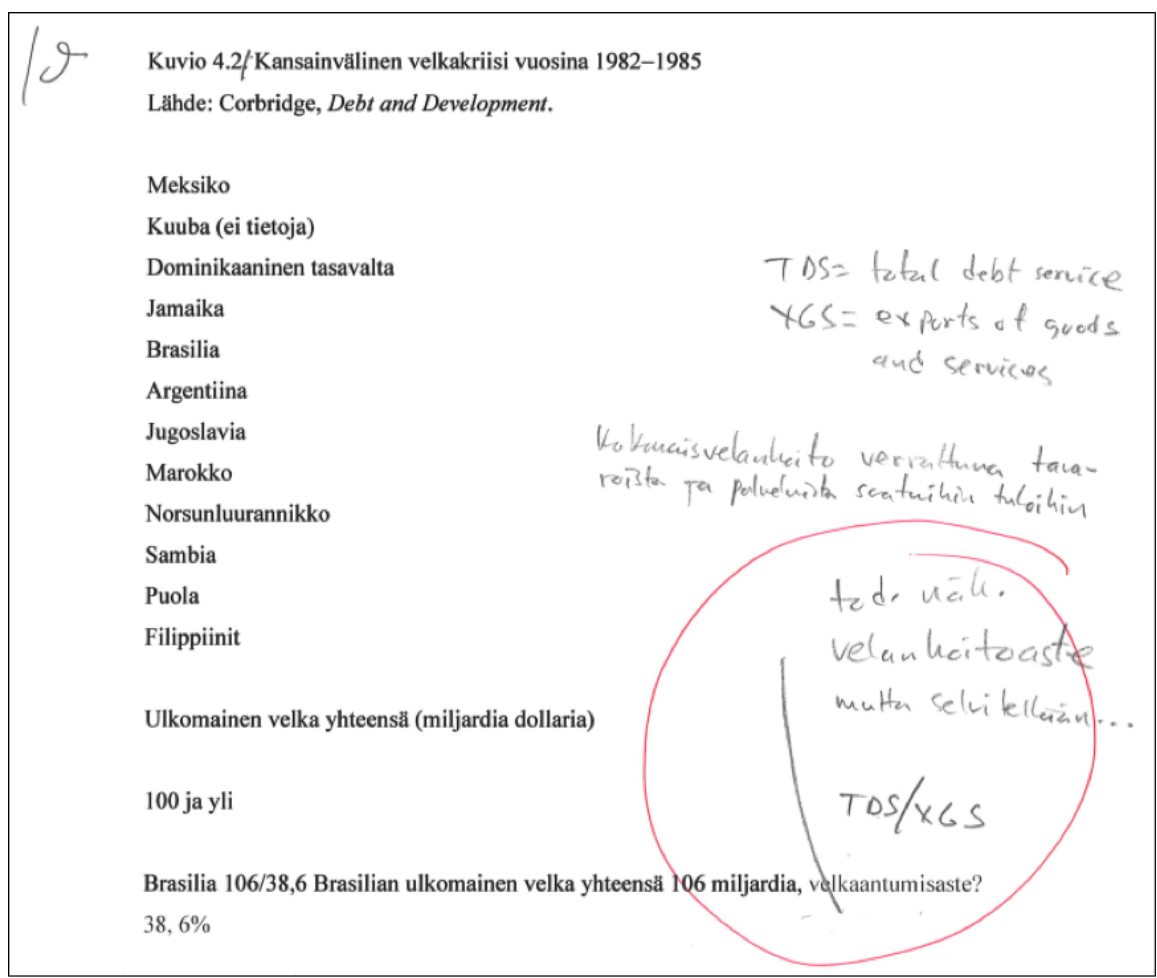

Kuva 2.

Kustannustoimittajan kommentit suomennoksen kuvion 2 käsitteeseen ja kääntäjän kysymykseen (velkaantumisaste?) (Suomennos, luku 4 s. 8) 
Kuten kuvasta 2 näkyy, suomentaja on merkinnyt tämän rivin lopun velkaantumisaste? $38,6 \%$ vaaleammalla värillä kuin muun tekstin. Sen yläpuolella on puolestaan kustannustoimittajan ympyröity merkintä: tod. näk. velanhoitoaste mutta selvitellään... Ympyröidyn yläpuolella puolestaan on kustannustoimittajan laajempi merkintä: TDS = total debt service / XGS = exports of goods and services / Kokonaisvelanhoito verrattuna tavaroista ja palveluista saatuihin tuloihin. Näissä merkinnöissä kustannustoimittaja ikään kuin purkaa auki alkutekstin tiivistettyä kuviota ja sen selityksiä.

Tämän voi tulkita nähdäksemme niin, että suomentaja saa tässä tietoa korjausehdotuksen taustaksi mutta samalla ympyröidyn tekstin ilmaus selvitellään kertoo, että kustannustoimittajan mielestä tätä käännösongelmaa ei ole vielä lopullisesti ratkaistu. Samalla se havainnollistaa sitä, millaista tiedonhakua akateemisen tietokirjan suomennostyöhön kuuluu ja että toimijat tekevät tätä työtä yhdessä.

\subsection{Historiallisesti latautuneet ilmaukset}

Käsitteillä on historiansa. Tekstissä esiintyvän yksittäisen käsitteen tulkinta nojaa siihen intertekstuaaliseen tietoon ja kokemukseen, joka lukijalla tai tekstin laatijalla on tieteenalasta ja sen diskursseista (Bakhtin 1986). Edellisen alaluvun esimerkit kertovat omalta osaltaan intertekstuaalisesta epäsymmetriasta (Blommaert 2007: 8), joka tarkastelemamme suomennos- ja julkaisuprosessin toimijoiden kesken vallitsee. Aineiston korjaukset ja kommentit tuovat esiin sen, että tekstienväliset suhteet ja viittaukset tulkitaan samassakin diskurssiyhteisössä ja yhteisöjen välillä usein eri tavoin. Historian myötä käsitteiden merkitykset ja konnotaatiot muuttuvat. Suomennosvaihtoehtoa haettaessa voi käydä myös niin, että valittu ilmaus onkin anakronistinen tai että se nykyhetkestä käsin viestii jotain tarpeetonta tai sopimatonta. Käsittelemme tässä alaluvussa kahta esimerkkiä, joissa on kustannustoimittajan mielestä kyse anakronistisesti käytetystä tai historiallisesti latautuneesta käsitteestä.

Esimerkki 17 kertoo Yhdysvaltain sekaantumisesta Nicaraguan politiikkaan 1920ja 1930-luvuilla. Suomentaja on ottanut käyttöön ilmauksen sandinistisissit, jolla kuitenkin tarkoitetaan, kuten kustannustoimittaja huomauttaa, 1970-luvulta alkaen toiminutta sissiliikettä.

(17) sandinistisissi $\rightarrow$ Augusto Sandinon johtama sissi

Toimintamalli syntyi Nicaraguassa 1920- ja 1930-luvuilla, jolloin Yhdysvaltain merisotilaat [ $\rightarrow$ merijalkaväki] määrättiin alueelle valvomaan USA:n etuja mutta [+ se] joutuivatkin[-vat] keskelle pitkää ja vaikeaa sandinistisissien $[\rightarrow$ Augusto Sandinon johtamien sissien] kapinaa. (Suomennos, luku 1 s. 22)

[The paradigm case was worked out in Nicaragua in the 1920 and 1930s, when US marines were deployed to protect US interests but found themselves embroiled in a lengthy guerilla insurgency led by Sandino. (S. 27)] 
(17') Kustannustoimittajan huomautus:

Kyse henkilöstä! tuolloin ei ollut termiä sandinistisissit, heistä alettiin puhua vasta $1970-$ luvulla

Suomentajan valinnan tekee kiinnostavaksi se, että sandinistisissi sinällään on varsinkin 1900-luvun viimeisinä vuosikymmeninä ollut laajalti käytössä Latinalaisen Amerikan tapahtumien uutisoinnissa ja edustaa varmasti monen alkuteoksenkin potentiaalisen lukijan mielestä 1970- ja 1980-luvuilla edistyksellisiä ja anti-imperialistisia voimia. Suomentajan valinta nostaa esiin tällaiset konnotaatiot ja ohjaa näin tekstin tulkintaa. Esimerkkimme osoittaa, kuinka käsitteiden käyttöä sätelevät historialliset tapahtumat, joihin ne liittyvät, mutta samalla se kertoo siitä, että niiden käyttöön ja tulkintaan vaikuttavat sekä alkutekstin ilmestymisajankohta että käännösprosessin ajankohta (ja lopulta käännöksen vastaanoton ajankohta). Blommaertin (2007: 4) skaalametaforaa hyödyntäen voisi puhua tulkinnallisista hyppäyksistä ajan, paikan ja yleisön skaaloilla. Blommaert (mas. 8-9) kuvaa käsitteiden latautuneisuutta ja historiallisesti latautuneiden tulkintojen vaihtelua ajan, paikan ja tulkitsijoiden mukaan seuraavasti:

- - terms are never sensitive to everyone, everywhere and all of the time - -. The terms operate - - at different scale-levels for the different groups, and at such levels the ideological load of these words changes from innocent and factual-descriptive to loaded and politically emblematic.

Kun ilmausta sandinistisissi käytetään esimerkissä 17 puhuttaessa 1900-luvun alun Nicaraguasta, sitä voi pitää anakronismina ja projektiona nykyisyydestä menneisyyteen. Vastaavasti aineistossamme hyödynnetään menneisyyteen ja menneiden aikojen diskursseihin kuuluvaa käsitteistöä puhuttaessa historiasta tai nykyisyydestä nykyhetken perspektiivistä. Myös tällaiset käännösratkaisut voidaan tulkita sopimattomiksi. Esimerkeissä 18-19 kustannustoimittaja reagoi lähes sanasta sanaan samalla tavalla suomentajan kahteen käsitevalintaan:

(18) yhtenäinen luokkarintama $\rightarrow$ kyky toimia luokkana

Työvoiman järjestäytyneen toiminnan heikentäminen (kuten Britanniassa ja Yhdysvalloissa), ohittaminen (kuten Ruotsissa) tai väkivaltainen tukahduttaminen (kuten Chilessä) on uusliberalisaation välttämätön ehto. Vastaavasti uusliberalismi on usein ollut sidoksissa liike-elämän ja suuryritysten kasvavaan valtaan, autonomiaan ja yhtenäiseen luokkarintamaan $[\rightarrow$ kykyyn toimia luokkana], joka on painostanut valtiovaltaa (kuten Yhdysvalloissa ja Ruotsissa). (Suomennos, luku 4 s. 30)

[By the same token, neoliberalization has frequently depended upon the increasing power, autonomy, and cohesion of business and corporations and their capacity as a class to put pressure on state power (as in the US and Sweden). (S. 116)] 
(18') Kustannustoimittajan huomautus: tämä on SKP:n kieltä!

(19) rahavallan keskus $\rightarrow$ finanssikeskus

Uusliberalistisen teorian nokkeluus on ollut siinä, että sen ihanalta kuulostavat iskusanat kuten 'vapaus', 'valinnanvapaus' ja 'oikeudet' ovat tarjonneet hyväntahtoisen naamion, joka peittää paljaan luokkavallan palauttamisen tai luomisen julman todellisuuden niin paikallisesti kuin ylivaltiollisesti, mutta etenkin globaalin kapitalismin rahavallan keskuksissa [ $\rightarrow$ finanssikeskuksissa]. (Suomennos, luku 4 s. 32-33)

[It has been part of the genius of neoliberal theory to provide a benevolent mask of wonderful-sounding words like freedom, liberty, choice, and rights, to hide the grim realities of the restoration or reconstitution of naked class power, locally as well transnationally, but most particularly in the main financial centres of global capitalism. (S. 119)]

(19') Kustannustoimittajan huomautus:

SKP-kieltä

(19") Suomentajan vastaus:

jaa@: - tulee multa ihan luonnostaan...

Kustannustoimittajan kommentit nostavat esiin tulkintakehyksen, joka varmasti osalle lukijoista aktivoituisi suomennosluonnosta lukiessa. Tämä tulkinta (SKP:n kieltä) on kytköksissä tulkitsijan intertekstuaaliseen tietoon ja kokemuksiin. 1900-luvulla aikuisikäänsä eläneen tai talouspoliittisen keskustelun historiaan perehtyneen on helppo ymmärtää kommenttien motivaatio - ja kenties myös olla yhtä mieltä kustannustoimittajan kanssa. Ei ole kuitenkaan vaikeaa kuvitella 2010-luvulle sellaistakaan lukijaa, jolle ilmaukset luokkarintama tai rahavalta eivät välttämättä kytkeydy mihinkään niin spesifiin kuin "SKP:n kieli"; ne korkeintaan vaikuttavat arkaaisilta tai muuten idiosynkraattisilta retorisilta valinnoilta. Käsitteiden mukanaan kantama historia on näkyvissä vain niille, jotka tuota historiaa tuntevat. Juuri tällaisissa tapauksissa ja niitä koskevissa käännösprosessin toimijoiden keskusteluissa tulee esiin käsitteiden kääntämisen vaikeus, varsinkin silloin, kun käännöksen lukijakunta ei ole tarkasti määriteltävissä. Esimerkissä 19 kustannustoimittajan kommentti implikoi, ettei "SKP-kieli" ole (käsillä olevassa) suomennoksessa toivottavaa. Tämän kommentin voi tulkita edustavan valistusfilosofiasta John Lockelta periytyvää rationalistista, puhtauden, objektiivisuuden ja selkeyden kieli-ideologiaa (vrt. Bauman \& Briggs 2003), jonka mukaan esimerkiksi (harhaanjohtavat, epäinformatiiviset) kielikuvat eivät ole suotavia tiedekirjallisuutta ja asiatekstiä tuotettaessa. Kääntäjän reaktio (jaa@) - tulee multa ihan luonnostaan...) hymiöineen karnevalisoi tällaisen normatiivisen suhtautumisen ja tarjoaa - toki leikillisesti - toisenlaista, luonnollista normia tekstin aiheesta puhumiseen. Samalla se on hyvä esimerkki editointiprosessin dialogisuuden monitasoisuudesta. 


\section{Lopuksi}

Tässä artikkelissa olemme pyrkineet osoittamaan, että kieli-ideologian käsite on hyödyllinen työkalu tutkittaessa käännösprosessia ja sen toimijoita. Analyysimme paljastaa, että kieli-ideologian käsitteen avulla on mahdollista ymmärtää paremmin tiedekirjojen suomentamisen kielellisiä valintoja ja niiden motivaatiota sekä jäsentää näiden valintojen suhdetta tieteenalan diskursiivisiin käytänteisiin ja kunkin alan diskurssiyhteisöjen muodostamaan yleisöön. Suomentajan ja kustannustoimittajan dialogin tarkastelu tuo esiin kaksi kieli-ideologioiden ominaispiirrettä: käännösprosessissa on läsnä samanaikaisesti keskenään kilpailevia ideologioita, ja eri kieli-ideologiat ovat kytköksissä erilaisiin polysentrisiin (Blommaert 2010) normijärjestelmiin. Eri kieli-ideologioiden samanaikainen aktivoituminen suomentajan valintojen, kustannustoimittajan korjausehdotusten sekä näiden kahden toimijan kommenttien muodostamassa dialogissa kertoo havainnollisesti siitä, että kielen käyttäjä on jatkuvasti valintojen edessä.

Tieteellisen teoksen käsitteiden suomentaminen on varsin konkreettinen kielellinen valinta, joka näyttää myös helposti kirvoittavan korjausehdotuksia ja kommentteja käännösprosessin osallistujilta. Kustannustoimittajan reaktiot, joita hän esittää suomennoksessa käytettyihin käsitteisiin käännösprosessin eri vaiheissa, kertovat kielenkäytön monivivahteisuudesta ja kielenkäytön kontekstien dynaamisuudesta ja kerroksellisuudesta. Korjausehdotukset, joissa kustannustoimittaja ehdottaa vierasperäisten käsitteiden tilalle kotoperäisiä ilmauksia, motivoituvat suomalaisen kielenhuollon pitkästä perinteestä, jonka yksi ideologinen piirre on vieraan vaikutuksen torjuminen purismin hengessä. Toisaalta hän voi myös tarjota kansainvälistä ilmausta kotoperäisen sanaston tilalle. Tämä puolestaan kertoo siitä, että suomentajalla ja kustannustoimittajalla voi olla erilainen näkemys tieteenalan kielenkäytön konventioista ja käytettävästä käsitteistöstä. Näissä tapauksissa on siis kyse toisenlaisesta purismista. Kotoja vierasperäisen ilmauksen lokaalinen vaihtelu - siten, että suomennostekstissä esiintyvät lähekkäin molemmat - voi myös selittyä sillä, että suomentaja haluaa välttää toistoa esteettisen tai retorisen normin perusteella. Taustalla on siis ideologinen käsitys siitä, millaista on kaunis (vrt. Herlin 2002) tai retorisesti vaikuttava kielenkäyttö. Myös taju siitä, millaiset käsitteet ovat kytköksissä mihinkin aikaan ja tutkimustraditioon, vaikuttaa siihen, miten niitä suomennoksessa käytetään ja miten niitä kommentoidaan. Kokonaisuudessaan analyysimme osoittaa sen, että tieteellisen teoksen käsitteiden kääntämisessä on otettava huomioon tieteenalojen diskurssiyhteisöjen käytänteet, tapa puhua - mutta myös se, että eri toimijoilla on erilaisia käsityksiä siitä, mitä nämä

käytänteet kunkin yksittäisen ilmauksen kohdalla ovat.

\section{Lähteet}

Agha, Asif 2007: Language and social relations. Cambridge: Cambridge University Press. Aineistonhallinnan käsikirja. Tampere: Yhteiskuntatieteellinen tietoarkisto. http://www.fsd.uta. fi/aineistonhallinta/fi/ (16.2.2017).

Auer, Peter - Wei, Li 2007: Introduction. Multilingualism as a problem? Monolingualism 
as a problem. - Peter Auer \& Li Wei (toim.), Handbook of multilingualism and multilingual communication s. 1-12. Berlin: Mouton de Gruyter.

BAкнtin, M. M. 1986: Speech genres and other late essays. Kääntänyt Vern W. McGee. Toimittaneet Caryl Emerson \& Michael Holquist. Austin: University of Texas Press.

Bauman, Richard - Briggs, Charles L. 2003: Voices of modernity. Language ideologies and the politics of inequality. Cambridge: Cambridge University Press.

Blommaert, Jan 2005: Discourse. A critical introduction. Cambridge: Cambridge University Press.

2007: Sociolinguistic scales. - Intercultural Pragmatics 4 s. 1-19.

2010: The sociolinguistics of globalization. Cambridge: Cambridge University Press.

Blommaert, Jan - Rampton, Ben 2011: Language and superdiversity. - Diversities 13 (2) S. 1-22.

Buzelin, HÉLÈne 2007: Translation studies, ethnography and the production of knowledge. - Paul St-Pierre \& Prafulla C. Kar (toim.), In translation. Reflections, refractions, transformations s. 39-56. Amsterdam: John Benjamins.

Chesterman, Andrew 2007: Kääntämisen normit. - H. K. Riikonen, Urpo Kovala, Pekka Kujamäki \& Outi Paloposki (toim.), Suomennoskirjallisuuden historia 2 s. 357-364. Helsinki: Suomalaisen Kirjallisuuden Seura.

Copland, Fiona - Creese, Angela - Rock, Frances - Shaw, Sara 2015: Linguistic ethnography. Collecting, analysing and presenting data. Los Angeles: Sage.

Fairclough, Norman 1992: Discourse and social change. Cambridge: Polity Press.

Gal, Susan - Woolard, Kathryn A. 2001: Constructing languages and publics. Authority and representation. - Susan Gal \& Kathryn A. Woolard (toim.), Languages and publics. The making of authority s. 1-12. Manchester, UK: St. Jerome Publishing.

Gumperz, John J. - Hymes, Dell (toim.) 1972: Directions in sociolinguistics. The ethnography of communication. New York: Holt, Rinehart and Winston.

Halonen, Mia - Ihalainen, Pasi - SAarinen, Taina (toim.) 2014: Language policies in Finland and Sweden. Interdisciplinary and multi-sited comparisons. Bristol: Multilingual Matters.

Helsingin yliopiston kieliperiaatteet 2014. Linjauksista käytäntöön - kohti toimivaa monikielisyyttä. Rehtorin päätös 25.9.2014. Helsinki: Helsingin ylipisto. https://jolu.it.helsinki.fi/ halvi/asianhallinta/dynasty/rehtori.nsf/cfa8ajbc4d8e1088c225782boo2b7d16/11d8c7938f84a 920c2257d5foo377oc8/\$FILE/Liite\%2orehtorin\%2op\%C3\%A4\%C3\%A4t\%C3\%B6kseen\%2O 98_2014.pdf (16.2.2017).

Herlin, IlONA 2002: Kauneus kielessä ja kielentutkimuksessa. - Ilona Herlin, Jyrki Kalliokoski, Lari Kotilainen \& Tiina Onikki-Rantajääskö (toim.), Äidinkielen merkitykset s. 407-431. Helsinki: Suomalaisen Kirjallisuuden Seura.

HiddenmaA, Pirjo 2003: Suomen kieli - who cares? Helsinki: Otava.

Hyvän virkakielen toimintaohjelma. Opetus- ja kulttuuriministeriön työryhmämuistioita ja selvityksiä 2014:2. Helsinki: Opetus- ja kulttuuriministeriö 2014. http://www.minedu.fi/ OPM/Julkaisut/2014/hyva_virkakieli.html?lang=fi (16.2.2017).

Hyvärinen, Matti - Kurunmäki, Jussi - Palonen, Kari - Pulkkinen, Tuija STENIUs, HeNRIK 2003: Käsitteet liikkeessä. Suomen politttisen kulttuurin käsitehistoria. Tampere: Vastapaino.

IRVINE, JUDith T. 2001: "Style" as distinctiveness. The culture and ideology of linguistic differentiation. - Penelope Eckert \& John R. Rickford (toim.), Style and sociolinguistic variation s. 21-43. Cambridge: Cambridge University Press. 
Irvine, Judith T. - Gal, Susan 200o: Language ideology and linguistic differentiation. - Paul V. Kroskrity (toim.), Regimes of language. Ideologies, polities, and identities s. 35-83. Santa Fe, New Mexico: School of American Research Press.

Kolehmainen, TARU 2014: Kielenhuollon juurilla. Suomen kielen ohjailun historiaa. Helsinki: Suomalaisen Kirjallisuuden Seura.

Kroskrity, Paul V. 2004: Language ideologies. - Alessandro Duranti (toim.), A companion to linguistic anthropology s. 496-517. Malden, MA: Blackwell.

lappalainen, Sirpa - Hynninen, Pirkko - Kankkunen, Tarja - Lahelma, Elina - Tolonen, TARjA (toim.) 2007: Etnografia metodologiana. Lähtökohtana koulutuksen tutkimus. Tampere: Vastapaino.

Leisi, ERnst 1947: Die tautologischen Wortpaare in Caxton's "Eneydos". Cambridge, MA: The Murray Print.

Lillis, THeresa 2008: Ethnography as method, methodology, and "deep theorizing". Closing the gap between text and context in academic writing research. - Written Communication 25 s. $353-388$.

- 2013: The sociolinguistics of writing. Edinburgh Sociolinguistics. Edinburgh: Edinburgh University Press.

LuCY, John J. 1992: Reflexive language and the human disciplines. - John J. Lucy (toim.), Reflexive language s. 9-32. Cambridge: Cambridge University Press.

Mäntynen, Anne 2003: Miten kielestä kerrotaan. Kielijuttujen retoriikkaa. Helsinki: Suomalaisen Kirjallisuuden Seura.

— 2012: Kieli-ideologiat käytännössä. Sanajärjestyksen normittuminen tietokirjojen suomennostyössä. - Virittäjä 116 s. 378-409.

_ 2013: Akateemisen tietokirjallisuuden suomennosprosessin erityispiirteitä. - Outi Paloposki \& H. K. Riikonen (toim.), Suomennetun tietokirjallisuuden historia 18oo-luvulta 200o-luvulle s. 322. Helsinki: Suomalaisen Kirjallisuuden Seura.

Mäntynen, Anne - Halonen, Mia - Pietikäinen, SAri - Solin, Anna 2012: Kieliideologioiden teoriaa ja käytäntöä. - Virittäjä 116 s. 325-348.

Mäntynen, Anne - Solin, Anna 2010: The local construction of language ideologies a discourse studies perspective. Esitelmä konferenssissa NorDisco 2010: Nordic Interdisciplinary Conference on Discourse and Interaction. Aalborg, Denmark 17.-19.11.2010.

NORDLUnd, TARU 2004: Arat taimet ja ankarat puutarhurit. 1800-luvun lopun kielikeskustelun metaforat ja kieli-ideologiat. - Katja Huumo, Lea Laitinen \& Outi Paloposki (toim.), Yhteistä kieltä tekemässä. Näkökulmia suomen kirjakielen kehitykseen 18oo-luvulla s. 286-322. Helsinki: Suomalaisen Kirjallisuuden Seura.

OntermaA, Aki 2005: Hilsettä ja herrastelua? Toisen infinitiivin instruktiivin ohjailu ja kielenhuollon ideologiat. - Ilona Herlin \& Laura Visapää (toim.), Elävä kielioppi. Suomen infiniittisten rakenteiden dynamiikkaa s. 318-343. Helsinki: Suomalaisen Kirjallisuuden Seura.

PASANEN, PäIVI 2015: Terminologinen käsiteanalyysi asiatekstin kääntäjän työvälineenä. - Sirkku Aaltonen, Nestori Siponkoski \& Kristiina Abdallah (toim.), Kä̈nnnetyt maailmat. Johdatus kä̈̈nnösviestintään s. 110-122. Helsinki: Gaudeamus.

Paunonen, Heikki 1994: Kielen normit ja kielen ohjailun normit. - Tiede \& Edistys 1/1994 S. $17-28$.

Pennycook, Alastair 2010: Language as a local practice. London: Routledge.

PIIPPO, IRINA 2012: Viewing norms dialogically. An action-oriented approach to sociolinguistic metatheory. Helsinki: Department of Modern languages, University of Helsinki. 
Pitkënen-Heikkilä, KaARina 2018: Tiedesanaston suomentamista koskevat normit. Eläintaksonomisen sanaston kehittämisestä 180o-luvulla ja 200o-luvulla. - Virittäjä 122 s. 523-56o. https://doi.org/10.23982/vir.57006.

Pulkkinen, PaAvo 1974: Asiasuomen opas. Seitsemäs painos. Helsinki: Otava.

RENKEMA, JAN 1982: Schrijfwijzer. Handboek voor duidelijk taalgebruik. 's-Gravenhage: Staatsuitgeverij.

Rintala, Päıvi 1992: Suomen kirjakielen normeista. - Sananjalka 34 s. 47-67.

— 1998: Kielikäsitys ja kielenohjailu. - Sananjalka 40 s. 47-65.

SaArimaA, E. A. 1947: Kielenopas. Porvoo: WSOY.

SajavaAra, Paula 2000: Kielenohjailu. - Kari Sajavaara \& Arja Piirainen-Marsh (toim.), Kieli, diskurssi \& yhteisö s. 67-106. Jyväskylä: Soveltavan kielentutkimuksen keskus, Jyväskylän yliopisto.

Silverstein, Michael 1985: Language and the culture of gender. At the intersection of structure, usage and ideology. - Elizabeth Mertz \& Richard J. Parmentier (toim.), Semiotic mediation s. 219-259. Orlando: Academic Press.

- 1992: Metapragmatic discourse and metapragmatic function. - John J. Lucy (toim.), Reflexive language s. 33-58. Cambridge: Cambridge University Press.

Suomen kielen tulevaisuus. Kielipoliittinen toimintaohjelma. Helsinki: Kotimaisten kielten tutkimuskeskus 2009.

Suomen tietokirjailijat ry: Tietokirjallisuuden lajit. http://www.suomentietokirjailijat.fi/jasenyys/liittyminen/tietokirjallisuuden-lajit/ (16.2.2017).

Swales, John M. 1990: Genre analysis. English in academic and research settings. Cambridge: Cambridge University Press.

Thomas, George 1991: Linguistic purism. London: Longman.

Tieteen termipankki. http://tieteentermipankki.fi/wiki/Termipankki:Etusivu (16.2.2017).

Titttula, Lissa - Ruusuvuori, Johanna 2005: Johdanto. - Johanna Ruusuvuori \& Liisa Tiittula (toim.), Haastattelu. Tutkimus, tilanteet ja vuorovaikutus s. 9-21. Tampere: Vastapaino.

Toury, Gideon 1995: The nature and role of norms in translation. - Gideon Toury, Descriptive translation studies and beyond s. 53-69. Benjamins Translation Library 4. Amsterdam: John Benjamins.

Vilok kinen, Natasha 2017: Tiedontuojat. Opas tietokirjan suomentajalle. Tampere: Vastapaino.

ViSA кко, Tомі 2015a: Promotionaalinen persoona semioottisena käyttäytymisenä. Verkon deitti-ilmoitukset lingvistisestä, semioottisesta ja antropologisesta näkökulmasta.

- Virittäjä 119, verkkoliite.

2015b: Self-promotion as semiotic behavior. The mediation of personhood in light of Finnish online dating advertisements. Helsinki: Department of Finnish, Finno-Ugrian and Scandinavian Studies, University of Helsinki.

Woolard, Kathryn A. 1998: Introduction. Language ideology as a field of inquiry. - Bambi B. Schieffelin, Kathryn A. Woolard \& Paul V. Kroskity (toim.), Language ideologies. Practice and theory s. 3-47. New York: Oxford University Press. 


\section{Dialogue on the choice and use of concepts: Language ideologies in the process of translating scholarly texts}

The article explores the translation of scholarly publications as an editorial process from the perspective of discourse studies. The analysis focuses on the dialogue between translator and editor regarding the choice and use of concepts, and specifically on what the translator's lexical choices, the editor's comments and the translator's reactions to these comments reveal about language ideologies.

The data consists of a manuscript of the Finnish translation of a scholarly publication, the comments on that manuscript made by both editor and translator, an interview with the translator, and other ethnographic data. The analysis uses qualitative discourse analysis as a methodological tool. Three different language-ideological phenomena are examined: the views of the translator and the editor on the use of 'foreign' linguistic elements; negotiations concerning any discipline-specific terms and concepts in the translated text; and dialogue concerning biased or historically loaded expressions.

Dialogue between the translator and the editor reveals that competing language ideologies exist simultaneously throughout the translation process, and that different language ideologies are linked to polycentric systems of norms. The participants' views on which concepts should be used when reporting on research findings in scholarly publications within a particular discipline vary according to their memberships of various discourse communities and according to their linguistic expertise.

The study shows that, when translating concepts in a scholarly text, translators follow the practices of the disciplinary discourse community. Furthermore, they have to be sensitive to the fact that when choosing between different options for the translation of a given concept, different actors may have a different understanding of the implications of these practices. The editor's reactions to the translator's choice of concepts can be explained by the dynamic and layered nature of the contexts of language use. When the editor proposes domestic expressions to replace foreign loan words, his action is motivated by the long-standing tradition of language policy which has rejected foreign influence on Standard Finnish. Occasionally, however, the editor may offer an international word as an alternative to a domestic expression used by the translator. One interpretation of this is that the translator and the editor have different views regarding the linguistic practices of the discipline and whether or not an expression belongs to the associated discourse. 


\section{Dialogia käsitteiden valinnasta ja käytöstä: Kieli-ideologiat tiedekirjallisuuden suomennostyössä}

Artikkelissa käsitellään tiedekirjallisuuden kääntämistä toimituksellisena prosessina 200o-luvun Suomessa diskurssintutkimuksen näkökulmasta. Artikkelissa sovelletaan kieli-ideologian käsitettä tieteenalan käsitteistön ja termien käännösprosessin tutkimukseen. Tarkastelun kohteina ovat suomentajan ja kustannustoimittajan käymä keskustelu käsitteiden valinnasta ja käytöstä sekä erityisesti se, mitä leksikaaliset valinnat, kustannustoimittajan kommentit sekä kääntäjän reaktiot kommentteihin kertovat kieliideologioista.

Tutkimusaineisto koostuu yhden tiedekirjasuomennoksen käsikirjoitusversioista, kustannustoimittajan ja kääntäjän käsikirjoitukseen tekemistä kommenteista sekä kääntäjän haastattelusta ja muista etnografisista havainnoista, joita analysoidaan laadullisesti diskurssintutkimuksen keinoin. Tutkimuksen kohteena on kolmenlaisia kieli-ideologisia ilmiöitä: käännösprosessiin osallistuvien suhtautuminen "vieraisiin" aineksiin, käännettävän teoksen tieteenalan diskurssille ominaisista ilmauksista käytävät neuvottelut sekä värittyneitä tai historiallisesti latautuneita ilmauksia koskevat keskustelut.

Analyysi paljastaa, että käännösprosessissa on läsnä samanaikaisesti keskenään kilpailevia ideologioita ja eri kieli-ideologiat ovat kytköksissä polysentrisiin normijärjestelmiin. Näkemykset siitä, millaisia käsitteitä tieteenalalla, sen tulosten julkaisemisessa ja niistä selostamisessa tulisi käyttää, vaihtelevat sen mukaan, millaisiin diskurssiyhteisöihin käännöksen parissa työskentelevät toimijat kuuluvat tai millaista kielellistä asiantuntijuutta he edustavat.

Tutkimus osoittaa, että tieteellisen teoksen käsitteiden kääntämisessä on otettava huomioon tieteenalojen diskurssiyhteisöjen käytänteet - mutta myös, että eri toimijoilla on erilaisia käsityksiä siitä, mitä nämä käytänteet kunkin yksittäisen ilmauksen kohdalla ovat. Kustannustoimittajan reaktiot suomentajan valitsemiin käsitteisiin kertovat kielenkäytön kontekstien dynaamisuudesta ja kerroksellisuudesta. Kun kustannustoimittaja ehdottaa vierasperäisen käsitteen tilalle kotoperäistä ilmausta, ehdotuksen taustalla on suomalaisen kielenhuollon perinteen ideologinen piirre, vieraan vaikutuksen torjuminen. Kustannustoimittaja saattaa myös tarjota kansainvälistä ilmausta kotoperäisen tilalle. Tämä puolestaan kertoo siitä, että suomentajalla ja kustannustoimittajalla voi olla erilainen näkemys tieteenalan kielenkäytön konventioista ja käsitteistöstä. Näissä tapauksessa on kyse toisenlaisesta purismista.

Kirjoittajien yhteystiedot (addresses):

etunimi.sukunimi@helsinki.fi

Kirjoittajat ovat suomen kielen professoreita Helsingin yliopistossa. 